\title{
Threats to Ultraoligotrophic Marine Ecosystems
}

\author{
Demetris Kletou and Jason M. Hall-Spencer \\ University of Plymouth, \\ United Kingdom
}

Remote marine areas with low productivity are amongst the least explored and understood ecosystems of the biosphere

\section{Introduction}

Marine phytoplankton account for $\sim 1 \%$ of the world's photosynthetic biomass but for nearly half of the world's primary production (Field et al., 1998; Bryant, 2003). Water bodies are often classified on the basis of surface chlorophyll a concentrations, the photosynthetic pigment that is present in all primary producers (Table 1).

$\begin{array}{ll}\text { Water body class } & \text { Chl. a }\left(\mathrm{mg} \mathrm{m}^{-3}\right) \\ \text { Ultraoligotrophic } & <0.06 \\ \text { Oligotrophic } & 0.06-0.1 \\ \text { Mesotrophic } & 0.1-0.3 \\ \text { Eutrophic } & 0.3-1 \\ \text { Hypertrophic } & >1\end{array}$

Table 1. Classification scheme based on chlorophyll a concentrations proposed by Shushkina et al. (1997).

Data from the Sea-viewing Wide Field-of-view Sensor (SeaWiFS) show that ultraoligotrophic marine areas occur within subtropical gyres at mid-latitudes and cover about 16-28\% of the Earth's surface (Fig. 1) (McClain et al., 2004). Despite their low productivity, subtropical gyres account for $30-50 \%$ of global oceanic primary productivity (Karl et al., 1996). The subtropical gyres of the North Pacific, North Atlantic, South Pacific, South Atlantic and South Indian Ocean are ultraoligotrophic year-round with the lowest productivity found in the South Pacific gyre near Easter Island (Morel et al., 2010). Periods of ultraoligotrophy also occur in the Eastern Mediterranean and the North Red Sea, particularly during summer (Labiosa et al., 2003; Siokou-Frangou et al., 2010). In this chapter we compare ultraoligotrophic areas and describe the main threats to these systems. 


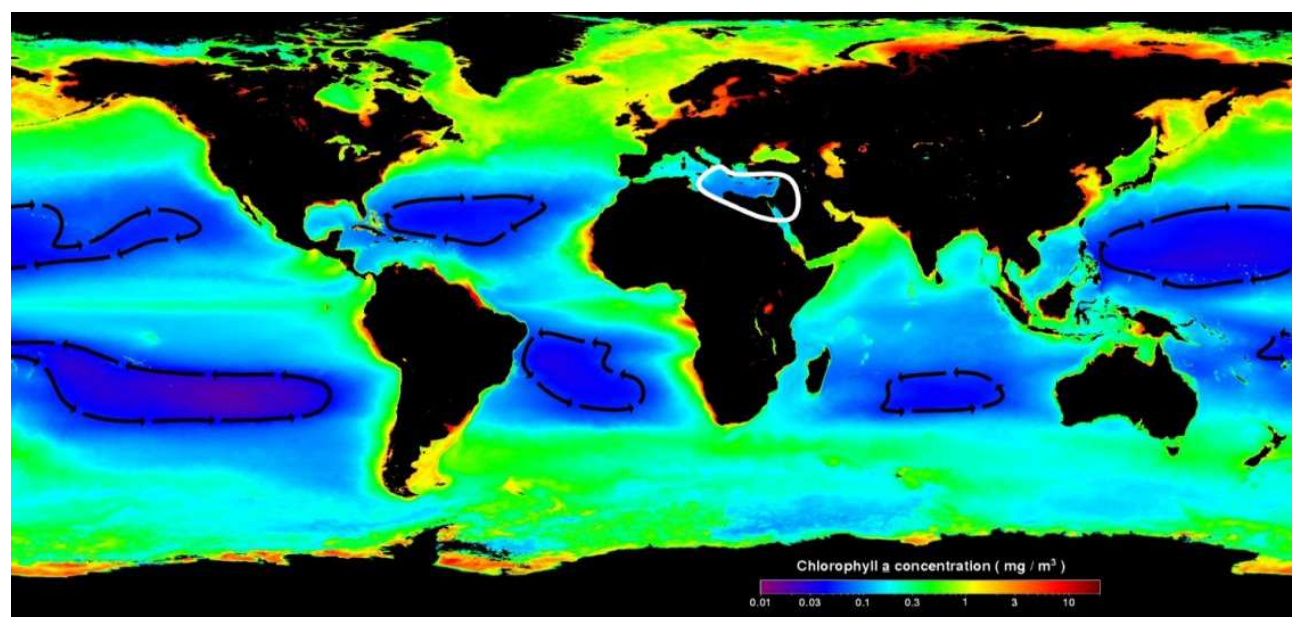

Fig. 1. World map of surface ocean chlorophyll-a concentration. Areas within black arrows and the white line indicate ultraoligotrophic $\left(<0.06 \mathrm{mg} \mathrm{m}^{-3}\right)$ open ocean and enclosed systems, respectively. Image from SeaWiFS Project NASA/GSFC and GeoEYE, data 19972010.

\section{Ultraoligotrophic ecosystems}

Satellite data underestimate phytoplankton productivity in ultraoligotrophic waters since light penetrates deep into the highly transparent waters, with distinct phytoplankton communities found at different depths and a peak in chlorophyll concentrations as deep as $150 \mathrm{~m}$ (Morel et al., 2007; Malmstrom et al., 2010). Phytoplankton sizes range from picoplankton $(0.2-2 \mu \mathrm{m}$ in diameter), through nanoplankton $(2-20 \mu \mathrm{m}$ in diameter) to microplankton $(>20-200 \mu \mathrm{m})$. Nutrient rich conditions favour microplankton (e.g. diatoms and dinoflagellates), which are large enough to be eaten by copepods and krill, that in turn are consumed by zooplanktivorous fish. These short, simple food webs have efficient energy transfer to larger consumers (Sommer et al., 2002). In ultraoligotrophic waters, picoplankton (Fig. 2) seem better able to acquire nutrients than large phytoplankton as they have a higher surface area to volume ratio (Raven, 1998). Picoplankton are too small to be ingested by copepods and instead are eaten by microplanktonic protists which then feed mesozooplankton (Christaki et al., 2002; Calbet, 2008) or they form aggregates that can then be consumed by crustacean and gelatinous zooplankton (Lomas \& Moran, 2011). The complex food webs that occur in ultraoligotrophic waters result in less efficient energy transfer to higher trophic levels. Ephemeral phytoplankton blooms can occur in ultraoligotrophic areas and during these events herbivorous plankton proliferate rapidly thanks to short generation times (Eden et al., 2009). During blooms myriads of vertically migrating grazers such as copepods, euphausiids and gelatinous zooplankton feed higher trophic groups such as squid, fish and other vertebrates (Seki \& Polovina, 2001).

Low phosphorous $(\mathrm{P})$ and nitrogen $(\mathrm{N})$ concentrations normally limit primary production in ultraoligotrophic systems. A spring peak in Chl. a concentrations usually occurs when longer days allow phytoplankton to thrive due to the greater nutrient availability that 
follows winter mixing (Morel et al., 2010). Competition for P may have shaped the evolution of marine microbes; the dominance of picocyanobacteria genera Prochlorococcus and Synechococcus in low P environments is thought to be due in part to their ability to form lipid membranes that require less P than most other organisms (Van Mooy et al., 2006; Dyhrman et al., 2009). Picocyanobacteria and picoeukaryotes carry genes encoding for enzymes like alkaline phosphatase (AP) that hydrolyze dissolved organic phosphorous (DOP) and PstS genes which are related to the high-affinity uptake of phosphate (Moore et al., 2005; Martiny et al., 2009). Many plankton are able to fix $\mathrm{N}_{2}$, although this ability can be limited by a lack of trace elements such as iron (Tyrrell, 1999; Kustka et al., 2003). The ability to fix $\mathrm{N}_{2}$ should be ecologically advantageous in ultraoligotrophic environments where the most abundant

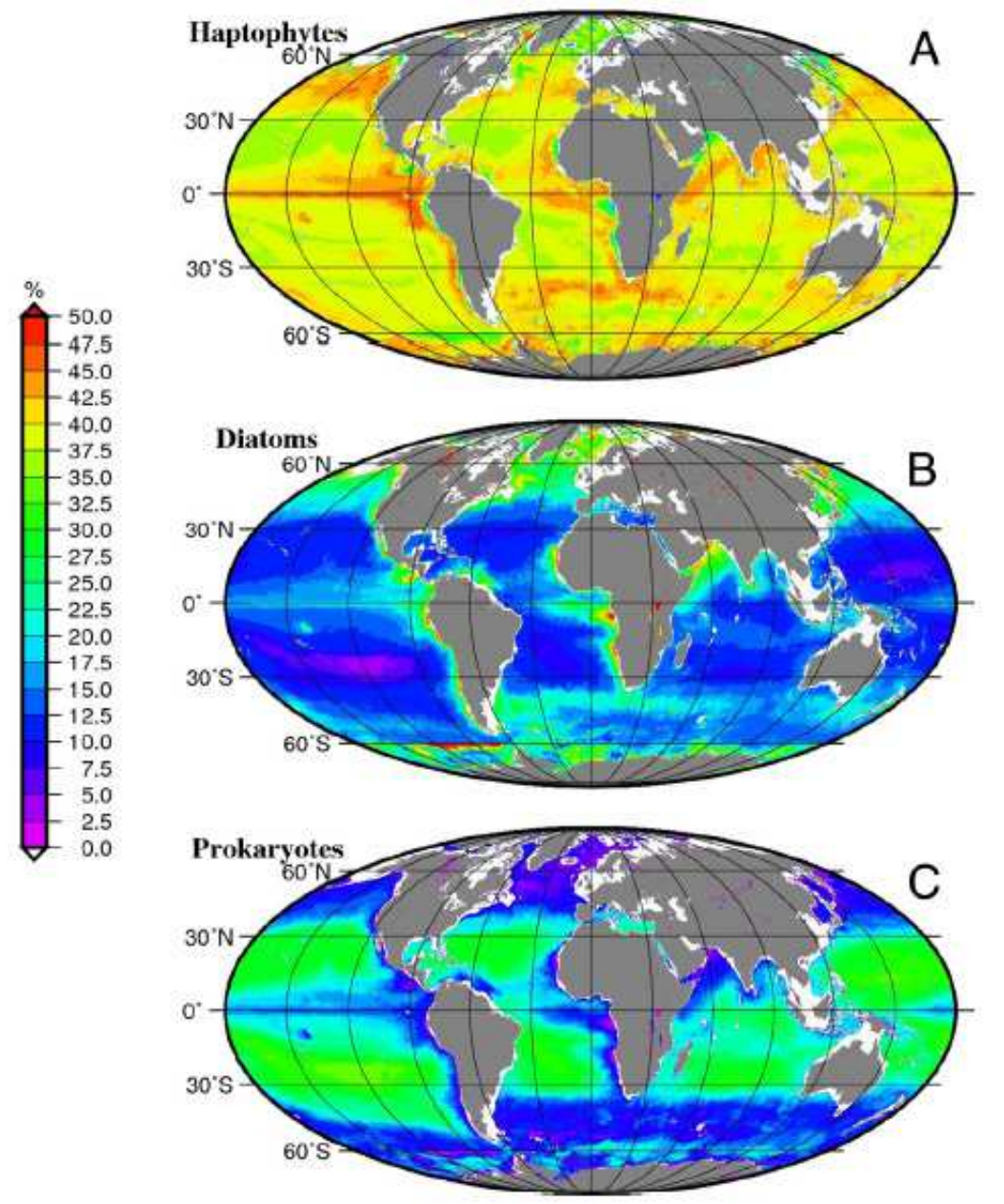

Fig. 2. Accessory pigments based on relative contribution of (A) haptophytes, (B) diatoms and $(\mathrm{C})$ photosynthetic prokaryotes to total Chl. a biomass in the euphotic layer for the year 2000. Image from Liu et al. (2009). 
forms of $\mathrm{N}$ are dissolved $\mathrm{N}_{2}$ gas and dissolved organic nitrogen (DON). In ultraoligotrophic surface waters $\mathrm{N}_{2}$ fixing bacteria typically have much lower abundances than non- $\mathrm{N}_{2}$ fixing cyanobacteria and picoeukaryotes but $\mathrm{N}_{2}$ fixation increases in importance with depth (Dekas et al., 2009). $\mathrm{N}_{2}$ fixing cyanobacteria, such as Trichodesmium spp., occur in many warm, calm and oligotrophic waters (Capone et al., 1997) and are a seasonal and episodic phenomenon in ultraoligotrophic waters. So far, research efforts have focused on colonial Trichodesmium spp. but free trichomes, which seem more important in oligotrophic systems, have received little attention (Taboada et al., 2010). Primary production in ultraoligotrophic areas is usually dominated by unicellular $\mathrm{N}_{2}$ fixing bacteria (e.g. Crocosphaera and UCYN clades), non- $\mathrm{N}_{2}$ fixing picocyanobacteria (e.g. Prochlorococcus and Synechococcus spp.) and small eukaryotes (e.g. haptophytes) (Malmstrom et al., 2010; Moisander et al., 2010). Surfaceocean microbial growth is mostly supported by regenerated production, such as DON (e.g. urea) and ammonia oxidation by nitrification which occurs in bacteria and archaea (Zehr \& Kudela, 2011).

Even though photosynthetic picoplankton are dominated numerically by Prochlorococcus and Synechococcus, much of the carbon is fixed by photosynthetic picoeukaryotes such as the exceptionally diverse haptophytes (Grob et al., 2011). Picohaptophytes are thought to contribute $30-50 \%$ of the total photosynthetic standing stock across the world ocean with their competitive success attributed to their mixed mode of nutrition as some are able to photosynthesize as well as engulf bacteria (Liu et al., 2009). Recent applications of molecular techniques demonstrate high diversity in the microbial parts of the food web (DeLong, 2009) and a previously unimagined diversity of eukaryotes (Massana \& Pedrós-Alió, 2008). Even though the phytoplankton abundance is lowest in oligotrophic waters, the diversity of small-sized phytoplankton seems to peak in these areas (Cermeño \& Figueiras, 2008; Kirkham et al., 2011). How such a diversity of plankton can coexist on limited resources is intriguing and was dubbed the 'paradox of plankton' by Hutchinson (1961). Explanations range from prolonged coexistence and niche segregation to mesoscale turbulence of the ocean (Roy \& Chattopadhyay, 2007; Perruche et al., 2010).

\subsection{Open ocean systems - Subtropical gyres}

Data from monitoring stations off Bermuda and Hawaii are revolutionizing our understanding of mid-latitude gyre dynamics. Once thought of as homogeneous unchanging ocean desserts, we now know that these ultraoligotrophic ecosystems are both physically and biologically dynamic. The gyres circulate clockwise in the northern hemisphere and anticlockwise in the southern hemisphere due to the Coriolis effect. Ekman pumping (water moving to the right of the wind) and geostrophic flow cause downwelling of relatively warm surface waters at the subtropical convergence near $20^{\circ}-30^{\circ}$ latitude (Pedlosky, 1998). The gyres have deep pycnoclines and even deeper nutriclines (e.g. nitrate, phosphate, and silicate) (McClain et al., 2004) and expand in area in summer. In most gyres Chl. a concentrations peak in spring following mixing in winter, while in the North Atlantic a secondary peak occurs at the end of September; in the North Pacific Chl. a concentration is higher during stratified conditions in the summer (Morel et al., 2010). Episodic blooms are also detected in all the gyres during stratified periods (Wilson \& Qiu, 2008). The ultraoligotrophic gyres are each ecologically distinctive, as illustrated by the differences in their primary producers. 


\subsubsection{North Atlantic}

The Sargasso Sea is probably the most studied open ocean system in the world (Steinberg et al., 2001). This subtropical gyre receives iron-rich Saharan dust (Marañón et al., 2010) but has extremely low $\mathrm{P}$ concentrations, possibly as a result of iron enhanced $\mathrm{N}_{2}$ fixation (Wu et al., 2000). In January-April waves deepen the mixed layer and bring nutrients into the euphotic zone. Subsequent stratification retains nutrients in the surface waters, promoting $\mathrm{N}_{2}$ fixation, primary production and blooms of phytoplankton such as Trichodesmium spp. (Taboada et al., 2010). As summer progresses the uptake of $\mathrm{P}$ by prokaryotes causes $\mathrm{P}$ limitation, although DOP is also utilised and can support $\sim 25-30 \%$ of annual primary production (Mather et al., 2008; Lomas et al., 2010). In summer a distinct shallow-water microbial community develops in the region of lowest nutrients, with a deep chlorophyll maximum community and an upper mesopelagic community (Treusch et al., 2009). Bacteria seem to be more concentrated in the surface waters while Archaea (e.g. Crenarchaeota) seem better adapted in the mesopelagic layer (Schattenhofer et al., 2009). Picoplankton (Prochlorococcus and Synechococcus spp. and picoeukaryotes) dominate carbon fixation in the subsurface chlorophyll maximum, while in surface waters the nanoplankton (e.g. some haptophytes, pelagophytes, small diatoms and dinoflagellates) make significant contributions to productivity (Poulton et al., 2006). Prochlorococcus is twice as abundant in the deep chlorophyll zone than at the surface, but is almost absent below $200 \mathrm{~m}$ (Schattenhofer et al., 2009; Riemann et al., 2011). Prochlorococcus clades have a succession of blooms as each responds differently to seasonal changes in light, temperature and mixing. Prochlorococcus peak in abundance during late summer and autumn whilst Synechococcus is scarce then but can occasionally become more abundant than Prochlorococcus during winter when the Sargasso Sea is more deeply mixed (Malmstrom et al., 2010).

Even though photosynthetic picoeukaryotes are less abundant than picocyanobacteria, they cause the observed variations in Chl. a and peak in abundance during winter/spring (Riemann et al., 2011). They are extremely diverse and dominated by haptophytes and chrysophytes, neither of which was traditionally considered to be important in carbon fixation (Kirkham et al., 2011). Rates of carbon fixation are comparable to those in the South Atlantic subtropical gyre and peak during the spring blooms (Poulton et al., 2006). The North Atlantic gyre appears to be net heterotrophic in autumn and balanced in spring (Gist et al., 2009) although it may be net autotrophic annually (Kähler et al., 2010). Despite being ultraoligotrophic, the Sargasso Sea is the spawning site of Atlantic eels. We now know that the picoplankton and nanoplankton make significant contributions to carbon export into deeper zones via settling of aggregates and/or consumption of those aggregates by mesozooplankton (Lomas \& Moran, 2011). In turn, mesozooplankton (e.g. heterotrophic athecate dinoflagellates and ciliates) feed copepods which may in turn be available to organisms at higher trophic levels, such as the larvae of Atlantic eels (Andersen et al., 2011).

\subsubsection{South Atlantic}

Much of our knowledge for the South Atlantic low nutrient gyre comes from the Atlantic Meridional Transect programme which has been undertaken semi-annually since 1995 along a $13,500 \mathrm{~km}$ transect between $50^{\circ} \mathrm{N}$ and $52^{\circ} \mathrm{S}$ (Robinson et al., 2009). Nutrient concentrations are lower than in the North Atlantic gyre, yet the southern system appears to be more autotrophic (Gist et al., 2009). $\mathrm{NO}_{3}$ - concentrations are below detection limits, and iron 
concentrations are also very low, but soluble reactive $\mathrm{P}$ is almost an order of magnitude higher than in the North Atlantic gyre. As $\mathrm{P}$ is a more bioavailable nutrient source than DOP reduced APA is detected which results in accumulation of DOP (Mather et al., 2008). The microbes seem to be adapted to higher organic loading and utilize organic inputs more efficiently than heterotrophic bacteria of the North Atlantic gyre (Martinez-Garcia et al., 2010). Unlike the North Atlantic gyre, $\mathrm{N}_{2}$ fixation is very low and is possibly limited by iron (Moore et al., 2009).

Prochlorococcus is more abundant than in the North Atlantic gyre although its contribution in the mesopelagic zone is minimal (Schattenhofer et al., 2009). SAR11 heterotrophs occur at lower abundances than in the North Atlantic gyre, but still make up about $25 \%$ of all picoplankton cells (Mary et al., 2006). Larger picoprokaryotes are found in the South Atlantic gyre compared to the North Atlantic (Schattenhofer et al., 2009). Small photosynthetic picoeukaryotes of a size $<3 \mu \mathrm{m}$ seem to play a crucial role in oceanic primary production. Phylogenetic analyses using both plastid and nuclear rRNA genes reveal a high diversity especially in the members of haptophytes and chrysophytes, with the latter dominating the South Atlantic gyre and associated with higher light intensities (Kirkham et al., 2011). Chrysophytes were previously only known from freshwater systems and their significance in marine oligotrophic areas is poorly understood.

\subsubsection{North Pacific}

Stratification of surface waters usually inhibits marine primary productivity as nutrients become depleted in the euphotic zone. However, at ALOHA monitoring station stratification and productivity are not strongly correlated (Dave \& Lozier, 2010). Presumably allochthonous nutrients maintain new production during stratified periods but it is not well understood how these nutrients are supplied. Unicellular diazotrophs frequently dominate $\mathrm{N}_{2}$ fixation in late winter and early spring, while filamentous diazotrophs (heterocystforming cyanobacteria and Trichodesmium spp.) fluctuate episodically during the summer (Church et al., 2009). The picocyanobacteria seem well adapted to P starvation by exhibiting significant increases in APA (Moore et al., 2005). In the past, a shift from eukaryotic to prokaryotic dominance transformed the North Pacific gyre from a N-limited to a P-limited system (Karl et al., 2001). There is now molecular evidence for an increase in N-limited strains of Prochlorococcus which may indicate that the gyre is returning to a N-limited phase (Van Mooy \& Devol, 2008).

Picophytoplankton are dominant contributors (averaging 91\%) to euphotic zone Chl. a concentrations (Li et al., 2011). Cyanobacteria such as Prochlorococcus spp. and heterotrophic bacteria, though incapable of $\mathrm{N}_{2}$ fixation, represent the vast majority of the total cell abundance throughout the euphotic layer (Duhamel et al., 2011). Proclorococcus spp. are numerically dominant year-round. Here plankton communities can be distinguished as epipelagic, mesopelagic and bathypelagic (Eiler et al., 2011) with distinct Prochlorococcus clades at different depths (Malmstrom et al., 2010).

In summer Chl. a concentrations peak, the phytoplankton is supported by $\mathrm{N}_{2}$ fixation and dominated by a few genera of large diatoms and the cyanobacterium Trichodesmium (Dore et al., 2008). Filamentous organisms, specifically heterocyst-forming cyanobacteria and Trichodesmium spp. fluctuate episodically during the summer resulting in highly variable 
fixation rates, possibly triggered by mesoscale physical processes (e.g. eddies, and windgenerated waves) that input nutrient rich waters in the euphotic zone and can cause blooms in the microbial communities (Fong et al., 2008).

There is uncertainty as to whether the system is a $C$ sink or source. Net community production is calculated to be closely balanced or slightly negative (net heterotrophic) due to tightly coupled respiration and gross community production (Viviani et al., 2011), but high oxygen concentrations below the mixed layer may be consistent with an ecosystem that is a net producer of fixed C (net autotrophic) throughout the year (Riser \& Johnson, 2008).

\subsubsection{South Pacific}

The South Pacific gyre is the largest oceanic gyre and has the clearest waters ever described with a chlorophyll maximum as deep as $180 \mathrm{~m}$ (Ras et al., 2008). Far from continental sources it receives the lowest atmospheric iron flux in the world (Wagener et al., 2008). Both phytoplankton and heterotrophic bacteria are limited by $\mathrm{N}$ within the centre gyre, but not by iron which only limits primary production at the border of the gyre (Bonnet et al., 2008). In the surface waters $(<180 \mathrm{~m}), \mathrm{NO}_{3}$ - is undetected and only trace quantities of regenerated $\mathrm{N}$ are found. Despite $\mathrm{N}$ limitation, no evidence of $\mathrm{N}_{2}$ fixation exists and nifH gene abundances are extremely low compared to North Pacific gyre (Bonnet et al., 2008). This suggests that the autotrophic communities are adapted to living at low iron levels, and that the common photoautotrophic $\mathrm{N}_{2}$ fixing organisms are not favoured due to their elevated iron quotas. In spite of strong $\mathrm{N}$ depletion leading to low chlorophyll biomass, the South Pacific gyre with its characteristic reduced vertical mixing can accumulate organic matter (Raimbault et al., 2008) that can sustain active regeneration processes during stratification (Raimbault \& Garcia, 2007).

In the clear waters of the gyre centre autotrophic eukaryotes shift to smaller cells $(<2 \mu \mathrm{m})$ compared to more eutrophic conditions (Masquelier \& Vaulot, 2008). Flow cytometry sorting carried out in the most oligotrophic areas of the gyre revealed several novel lineages of photosynthetic picoeukaryotes such as a clade of prasinophytes. Pelagophytes, chrysophytes and haptophytes are the dominant picophytoplankton (Shi et al., 2011). Coccolithophores are an important group of unicellular calcifying haptophytes, even though at low abundances they grow down to $300 \mathrm{~m}$ deep with maximum cell concentrations recorded between the depths of 150-200m (Beaufort et al., 2008). In addition, high taxonomic diversity is also detected in the microzooplankton tintinnids that is inversely related to chlorophyll concentration and positively to the depth of the maximum chlorophyll layer (Dolan et al., 2007). Furthermore, larger microplankton (e.g. diatoms) can adapt to the ultraoligotrophic conditions of this region by forming symbiotic relationships with other species (Gómez, 2007).

There is now growing evidence that this oceanic expanse, once thought to be net heterotrophic may be net autotrophic. The deep layers, below the euphotic zones, may be significant contributors to $\mathrm{C}$ fixation fuelling heterotrophic processes in the upper layer (Claustre et al., 2008 ). However this remains a debate; as some studies show that net community production is closely balanced or slightly net heterotrophic (Viviani et al., 2011) while data from oxygen sensors deployed on profiling floats suggest that the system is net autotrophic throughout the year (Riser \& Johnson, 2008). 


\subsubsection{South Indian}

The Indian subtropical gyre is probably the least studied gyre. Research has so far focused in the Arabian Sea (north-western Indian Ocean) and extensive regions of the oceanic gyre remain unknown. In late winter (austral summer) warm and salty subtropical water is separated from deeper water (Tsubouchi et al., 2009). This pronounced vertical stratification impedes nutrient transport into the euphotic zone leading to low seasonal $\mathrm{NO}_{3}{ }^{-}$and $\mathrm{Si}(\mathrm{OH})_{4}$ concentrations that limit primary production by microplankton so that nanoplankton and picoplankton dominate productivity. The turnover rate of nanoplankton and picoplankton seems to be closely coupled to microzooplankton grazing and low nutrient concentrations (Thomalla et al., 2010).

About $90 \%$ of Chl. a observed at the surface and at the deep chlorophyll maximum (up to $120 \mathrm{~m}$ depth) is attributed to the picophytoplankton fraction, while picoeukaryotes account for up to $50 \%$ of the Chl. a measured (Not et al., 2008). Prokaryotic Prochlorococcus and eukaryotic prochlorophytes, haptophytes and pelagophytes seem to dominate the oligotrophic waters of the Indian Ocean, though a large fraction of the eukaryotic genomes sampled and a significant flagellate (small phototrophic protist) remain unidentified (Not et al., 2008; Schlüter et al., 2011). Greater variation in the picoeukaryotic assemblages has been observed vertically in the upper $200 \mathrm{~m}$ of the water column than horizontally across the entire southern Indian oceanic expanse.

\subsection{Enclosed systems}

The low primary production observed in open-ocean subtropical gyres relates to their isolation from freshwater and airborne nutrient sources. Few coastal regions are ultraoligotrophic, although the Eastern Mediterranean and the Northern Red Sea become ultraoligotrophic during the warmer parts of the year (Labiosa et al., 2003; Siokou-Frangou et al., 2010).

\subsubsection{Eastern Mediterranean}

The Mediterranean connects through the Strait of Gibraltar to the Atlantic Ocean in the west, the Bosporus Strait to the smaller enclosed Black Sea in the northeast, and the Suez Canal to the Red Sea and Indian Ocean in the southeast. Evaporation exceeds precipitation and river run off (the main rivers are the Ebro, Rhone, Po, Danube and Nile) with surface waters increasing in salinity from west to east. Atlantic surface water enters through the Strait of Gibraltar and moves eastwards, sinking to $200-500 \mathrm{~m}$ depth in the Eastern Mediterranean before circulating back west and exiting through the Strait after about 80-100 years and with nearly $10 \%$ more salt content (Bas, 2009).

Nutrients mainly enter the system through the Straits of Gibraltar and Bosporus, from winddriven Saharan dust deposits and from river discharges mainly in the north. The Eastern Mediterranean has the lowest nutrient content. Here dams have resulted in drastic reductions in freshwater flow; the Aswan dam on the Nile, for example, restricts the amount of silica entering the Mediterranean (Turley, 1999). In the Eastern Mediterranean aeolian inputs can account for $60-100 \%$ of the bioavailable N and $30-50 \%$ of the bioavailable P (Krom et al., 2010). The unusually high ratio of $\mathrm{N}$ to $\mathrm{P}(\sim 28: 1)$ observed in the Eastern Mediterranean (it can sometimes reach 105:1) is due to high $\mathrm{N}$ inputs from rivers and atmospheric deposition (Krom et al., 2010; Markaki et al., 2010). 
In the western Mediterranean, winter mixing of surface waters with nutrient-rich deeper waters causes a winter-spring phytoplankton bloom composed mostly of diatoms with some flagellates and coccolithophorids (Goffart et al., 2002). The bloom is less-pronounced in the Eastern Mediterranean (D'Ortenzio \& Ribera d'Alcalà, 2009), Chl. a concentration is $<0.1 \mathrm{mg} \mathrm{m}^{-3}$ on average, with the maxima occurring in late winter - early spring and minima in late summer (Siokou-Frangou et al., 2010). In summer a sharp thermocline at 10-20m results in nutrient depletion in the surface mixed layer. During this stratified period, primary production in the Eastern Mediterranean is both $\mathrm{N}$ and $\mathrm{P}$ limited, and during the winter mixing it becomes P limited (Thingstad et al., 2005; Tanaka et al., 2011). As in other ultraoligotrophic systems, the microbial loop is in a dynamic equilibrium in which grazing pressure, competition and nutrient concentrations can shift the limiting nutrient.

The importance of $\mathrm{N}_{2}$ fixation in the Eastern Mediterranean is under investigation. There are low concentrations of diazotrophic cyanobacteria, possibly due to $\mathrm{P}$ and iron limitation. The $\mathrm{N}_{2}$ fixation rates decrease from west-east but may sustain up to $35 \%$ of the primary production in the eastern basin and can be stimulated occasionally by Saharan dust events (Bonnet et al., 2011; Ridame et al., 2011) The diazotrophic community is dominated by unicellular picocyanobacteria, although $\mathrm{N}_{2}$ fixation has also been detected within picoeukaryotes (Le Moal et al., 2011).

Picoplankton dominate the most nutrient limited areas of the Mediterranean (Tanaka et al., 2007). Larger diatoms and dinoflagellates become abundant after intermittent nutrient pulses associated with upwelling, fronts and gyres (Siokou-Frangou et al., 2010). Over 85\% of Chl. a in the eastern basin is found in ultraplankton $(<10 \mu \mathrm{m})$, that comprises cyanobacteria (Synechococcus spp. are dominant), chlorophytes, prasinophytes and haptophytes (Denis et al., 2009). Coccolithophores are more abundant and diverse in the eastern basin (Ignatiades et al., 2009). In summer, dinoflagellates dominate the larger plankton fraction in offshore areas of the Eastern Mediterranean whereas diatoms are more prevalent during winter mixing and in inshore waters where anthropogenic eutrophication is evident (Aktan, 2011).

Most studies describing phytoplankton biomass dynamics in the Mediterranean Sea stress that low nutrients cause low primary production (bottom-up control). However, the planktonic food webs are very efficient at minimizing $C$ export to deeper waters, benefiting predators that control the plankton biomass (top-down control) (Siokou-Frangou et al., 2010). A P addition experiment in the Eastern Mediterranean had an unexpected outcome because Chl. a concentrations decreased while egg-carrying copepods numbers increased (Krom et al., 2005; Thingstad et al., 2005). Efficient top-down control helps explain why Mediterranean fisheries are richer than anticipated based on Chl. a and nutrient concentrations. In addition to efficient $C$ export to pelagic top predators, benthic primary producers also play an important role in sustaining Eastern Mediterranean food webs. Highly productive benthic primary producers, such as the seagrass Posidonia oceanica which grow at $0-50 \mathrm{~m}$ in depth (Duarte, 1991) the coralline algal habitats (e.g. maerl) which grow in low light conditions (Ballesteros, 2006) and macroalgal assemblages (e.g. Cystoseira forests) in the shallows form diverse and complex habitats. The Mediterranean basin ranks among 25 'biodiversity hotspots' containing about $7 \%$ of the world's marine biodiversity (Bianchi \& Morri, 2000; Myers et al., 2000). Even though it covers $<0.8 \%$ of the world ocean surface and is $<0.3 \%$ of its volume, it is home to $4-18 \%$ of the world's recorded species, 
depending on the phylum considered. Approximately 17000 marine species occur in the Mediterranean Sea and this inventory is expanding rapidly, especially for microbes and deep sea species (Coll et al., 2010). An unusually high level of endemism is observed and the region hosts a number of species of conservation interest, such as 71 species of sharks, rays and chimaeras (Cavanagh \& Gibson, 2007), sea turtles (Dermochelys coriacea, Chelonia mydas, Caretta caretta), nine permanent resident species of cetaceans (Reeves \& Notarbartolo, 2006) and the critically endangered Mediterranean monk seal (Monachus monachus). The southeastern Mediterranean Sea has, on paper, the lowest species richness but this is influenced by the fact that there have been relatively sparse research efforts in this part of the Mediterranean.

\subsubsection{North Red Sea}

The Red Sea is thought to owe its name to intense phytoplankton blooms but they are very rare in this oligotrophic system. It connects to the Mediterranean Sea through the narrow and shallow $(\sim 8 \mathrm{~m})$ Suez Canal in the north and exchanges water with the Indian Ocean through the Bab el Mandeb strait (130m deep) and the Gulf of Aden in the south. There are no permanent rivers and scant rainfall so seawater entering through the Bab el Mandeb strait gets saltier as it progresses northwards. Like the Mediterranean Sea, the North Red Sea is heavily influenced by seasonal changes in physical and chemical characteristics of the water column. Oligotrophic to ultraoligotrophic conditions prevail in the northern region during the summer and autumn stratified period, while in the winter, conditions become eutrophic (Lindell \& Post, 1995; Labiosa et al., 2003). The Gulf of Aqaba, at the northeast tip of the Red Sea is about $165 \mathrm{~km}$ long, very deep $(\sim 1800 \mathrm{~m})$ but very narrow (max width $<25 \mathrm{~km})$, bounded by desert and separated from the Red Sea by the shallow $(240 \mathrm{~m})$ Strait of Tiran. Here, phytoplankton populations have a large spring bloom (with Chl. a peak at around $3 \mathrm{mg} \mathrm{m}^{-3}$ ) and smaller autumn bloom but in the summer levels average $\sim 0.2 \mathrm{mg} \mathrm{m}^{-3}$ (Labiosa et al., 2003).

Although N:P ratios are lower in the summer many phytoplankton species appear to be $\mathrm{P}$ limited and even though $\mathrm{P}$ is below detection limits, APA is consistently low in the picophytoplankton fraction indicating the absence of $\mathrm{P}$ limitation, while larger phytoplankton express increased APA especially during the stratified period indicating $\mathrm{P}$ limitation (Mackey et al., 2007). $\mathrm{N}_{2}$ fixation rates are consistently low and are higher during the deep mixing season. Diazotrophic populations are dominated by the smaller $\mathrm{N}_{2}$ fixing organisms (Foster et al., 2009). Small unicellular cyanobacteria (e.g. Cyanothece spp.), are the most abundant $\mathrm{N}_{2}$ fixing organisms, while larger filamentous Trichodesmium occur in surface waters especially in the winter when soluble reactive P is more abundant (Mackey et al., 2007). Inputs of aerosol $\mathrm{NO}_{3}$ - to surface waters represents an important source of 'new ' $\mathrm{N}$ in this region (Aberle et al., 2010).

The planktonic communities are characterized by low abundances and the dominance (95\%)

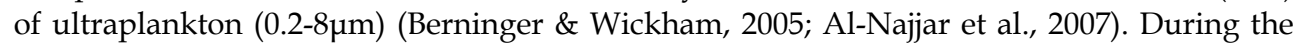
summer and autumn, stratified surface waters become nutrient depleted and picophytoplankton dominate. In winter, nutrient concentrations increase and larger phytoplankton become more abundant. This pronounced seasonal succession of major taxonomic groups is observed with Prochlorococcus dominating during the stratified summer 
period but being almost absent during the winter and chlorophytes with cryptophytes dominating during the winter mixing but being almost absent during the summer (Al-Najjar et al., 2007). Larger cells $(>8 \mu \mathrm{m})$ are dominated by dinoflagellates and ciliates (Berninger \& Wickham, 2005). The ciliates prey on the dominant picoautotrophs so that this primary production then becomes available to metazoan grazers (Claessens et al., 2008). Stable isotope analyses revealed a complex and diverse planktonic community that included herbivores and a large variety of omnivores (e.g. non-calanoid copepods) (Aberle et al., 2010). It appears top-down and bottom-up controls operate simultaneously in the North Red Sea with small cells being controlled by grazing while larger cells (e.g. diatoms) are limited by nutrient availability (Berninger \& Wickham, 2005).

Despite periods of ultraoligotrophic conditions, the Red Sea is a biodiversity and endemism hotspot (Roberts et al., 2002). The Gulf of Aqaba is characterized by very high levels of endemism, especially in the mollusc and echinoderm taxa and there are exceptionally diverse fringing reefs, steeply sloping to depths of up to $150 \mathrm{~m}$ (Fricke \& Schuhmacher, 1983).

\section{Threats}

The human population now exceeds 7 billion compared to around 800 million in the year 1750 and an estimated 9.4 billion by 2050 (Raleigh, 1999; United States Census Bureau, 2011). This rapid population increase has been matched with environmental degradation and global biodiversity loss. Marine litter is now ubiquitous, and resources are being exhausted at alarming rates. The major stressors of anthropogenic climate change on the world's marine ecosystems are warming, acidification and deoxygenation (Gruber, 2011) with impacts that range from decreased ocean productivity, altered food web dynamics, reduced abundance of habitat-forming species, shifting species distributions, and a greater incidence of disease (Hoegh-Guldberg \& Bruno, 2010). In this section we consider how ultraoligotrophic marine ecosystems are being altered by Man, and to what extent these systems may be vulnerable to the multiple stressors that are present.

\subsection{Open ocean systems}

Subtropical open ocean ecosystems are far removed from human civilization yet despite this remoteness rapid changes are underway, such as ocean acidification and the accumulation of marine debris.

\section{Climate change}

Remotely-sensed ocean colour data show that ultraoligotrophic marine regions have expanded by about 15\% in the past decade (Polovina et al., 2008) and that the growth of these provinces may be accelerating as they get larger (Irwin \& Oliver, 2009). Significant decreases in Chl. a concentrations have also been recorded in most subtropical gyres (Signorini \& McClain, 2011). Polovina et al. (2011) predict that ocean warming will expand the area of the subtropical biome by $\sim 30 \%$ by 2100 due to increased water stratification and restricted supplies of nutrients to the upper water column. In such areas, large and efficient $\mathrm{C}$ fixing eukaryotic species are outcompeted by smaller eukaryotic and prokaryotic plankton causing productivity to fall. 
During the past 100 years, rising atmospheric greenhouse gas concentrations have increased global surface ocean temperatures by $\sim 0.7^{\circ} \mathrm{C}$ (Trenberth et al., 2007). The deep ocean remains relatively cool, so a density gradient is developed which increases upper ocean stratification which can lower the oxygen and nutrient contents of the water. Ocean warming and increased stratification of the upper ocean may lead to $1-7 \%$ declines in dissolved oxygen in the ocean interior with implications for ocean productivity and nutrient cycling (Keeling et al., 2010). Large expansions of the oxygen minimum zones have occurred horizontally and vertically in all tropical and subtropical oceans and it is estimated that since 1960 deoxygenated areas have increased by 4.5 million $\mathrm{km}^{2}$ (Stramma et al., 2010). The implications of ocean warming and deoxygenation on the functioning of ultraoligotrophic systems are poorly known yet alterations in food webs can be expected since warming will favour some microbes and plankton over others (Marinov et al., 2010; Sarmento et al., 2010).

Ocean acidification results from the uptake of anthropogenic carbon dioxide $\left(\mathrm{CO}_{2}\right)$ of which around one third is absorbed by the oceans (Sabine et al., 2004) where it reacts with water to form carbonic acid $\left(\mathrm{H}_{2} \mathrm{CO}_{3}\right)$ which further dissociates into hydrogen ions $\left(\mathrm{H}^{+}\right)$and carbonate ions $\left(\mathrm{CO}_{3}{ }^{2-}\right)$. Increased $\mathrm{H}^{+}$ions lower the $\mathrm{pH}$ of the water. Surface waters of the oceans have been acidified by an average of $0.1 \mathrm{pH}$ units compared with pre-industrial levels (Doney, 2010). Model simulations predict that ocean $\mathrm{pH}$ will decrease by 0.2 to $0.3 \mathrm{pH}$ units by the end of the twenty first century (Orr et al., 2005). The ecological effects of ocean acidification remain uncertain yet there are widespread concerns over the effects on calcified organisms since uptake of atmospheric $\mathrm{CO}_{2}$ leads to a decrease in carbonate concentrations and increases $\mathrm{CaCO}_{3}$ dissolution (Riebesell et al., 2009; Rodolfo-Metalpa et al., 2011). The calcifying plankton that occur in ultraoligotrophic systems (e.g. coccolithophores, foraminiferans, and pteropods) may have a reduced ability to construct their $\mathrm{CaCO}_{3}$ shells. Beaufort et al. (2011) for example found a significant decrease in coccolith mass at sites all over the world as $p \mathrm{CO}_{2}$ concentrations increase, although there were exceptions with a heavily calcified coccolith morphotype found in some low $\mathrm{pH}$ areas. Biogeochemical disruptions are also possible due to ocean acidification, although the ecological effects of these remain unknown. For example experimental decreases in $\mathrm{pH}$ lower microbial nitrification (oxidation of ammonia into nitrite) rates (Beman et al., 2011). When stimulated by $p \mathrm{CO}_{2}, \mathrm{~N}_{2}$ fixation rates appear to increase in filamentous non-heterocystous Trichodesmium spp. (Barcelos e Ramos et al., 2007) and the unicellular Crocosphaera watsonii (Fu et al., 2008), but decrease in heterocystous diazotrophs (Czerny et al., 2009). Changes in nitrification and $\mathrm{N}_{2}$ fixation rates have the potential to cause fundamental alterations to the marine environment. Elevated $p \mathrm{CO}_{2}$ in cultured organisms and in a few mesocosms reveal contradicting results with some prokaryotic species and communities exhibiting increased production when others are adversely impacted (Liu et al., 2010). It is clear that our understanding of the potential impacts of acidification on the overall biogeochemistry of marine waters is limited by the lack of in situ experiments (except in some coastal areas with $\mathrm{CO}_{2}$ vents) and the inconsistency or lack of data for several taxa. Predicting changes to marine ecosystems is also problematic since decreasing $\mathrm{pH} /$ increasing $\mathrm{CO}_{2}$ is occurring in combination with other changes such as deoxygenation and warming (Denman et al., 2011).

\section{Marine debris}

During the last 60 years, the global production of plastic has increased from 1.5 million tonnes to 265 million tonnes (Plastics Europe, 2011). The light plastic particles (e.g. 
polyethylene and polypropylene) that enter water bodies then float and drift with the currents and can be transported over large distances. The subtropical gyres trap floating debris in the central slower moving water masses. Accumulating plastic was discovered in 1972 in the Sargasso Sea, with increasing amounts recorded with time, such as in the North Pacific gyre where up to 334,271 pieces per $\mathrm{km}^{2}$ and a startling 6:1 biomass ratio of zooplankton to plastic were recorded (Moore et al., 2001). Similar observations have been made in the North Atlantic gyre (Law et al., 2010). Models and observations show that all five subtropical gyres are litter aggregation hotspots (Maximenko et al., 2011).

Plastic can degrade to microscopic pieces (Thompson et al., 2004) that adsorb persistent organic pollutants such as PCBs, PAHs, DDTs, PBDEs, alkylphenols, and bisphenol A (Rios et al., 2010). Planktonic plastic loaded in organic pollutants can easily be mistaken for prey and upon ingestion the pollutants bioaccumulate (Harwani et al., 2011), while the plastic remains undigested and can sometimes clog the digestive tract of the organism leading to starvation and subsequent death. Top predators have been consistently reported victims of this plastic menace; $34 \%$ of 408 dissected leatherback turtles (Mrosovsky et al., 2009), 28\% of 106 dolphins incidentally captured in artisanal fisheries (Denuncio et al., 2011) and 9.2\% of 141 mesopelagic fishes from 27 species in the North Pacific subtropical gyre (Davison \& Asch, 2011) had plastic in their stomachs. Every albatross chick egested bolus examined from the North Pacific colonies contained plastic (Young et al., 2009). 134 different types of nets causing stomach rupturing and emaciation were found inside two stranded male sperm whales in Argentina (Jacobsen et al., 2010), and the list goes on. It is now recognized that the environmental impacts of plastic debris are wide-ranging and include among others entanglement of marine fauna, ingestion by consumers from all trophic levels including the small heterotrophic plankton, dispersal of invasive species to non-native waters, and bioaccumulation of organic contaminants (Gregory, 2009).

How the biocommunities inhabiting the deoxygenated, acidified, warm waters of the ultraoligotrophic subtropical gyres will respond to changes brought about by the 'Marine Debris Era' remains to be seen.

\subsection{Enclosed systems}

Due to the proximity of humans, enclosed ultraoligotrophic systems are exposed to multiple anthropogenic stressors. The benefits supplied by marine biodiversity to human health are enormous and include: i) seafood (high-quality protein, minerals and vitamin D and omega3 fatty acids) with antioxidant properties and cardio and cancer protective effects, ii) marine organisms such as sharks, algae and sponges supply a large variety of bioactive metabolites some of which are used to treat human diseases and, iii) maritime leisure activities such as recreational provide physical and psychological effects to users such as recreational fisheries, diving, snorkelling, and whale watching (Lloret, 2010). To sustain such benefits improvements are required in the ways that we manage ultraoligotrophic seas.

The North Red Sea is a biodiversity hotspot with high levels of endemism and stunning fringing reefs that can extend to depths of $150 \mathrm{~m}$. Protecting the threatened coral reefs of the enclosed North Red Sea is a real challenge as there are multiple stressors already in effect. Ocean warming slows coral growth and increases bleaching events (Cantin et al., 2010). Future acidification is a significant threat that is expected to increase bioerosion and 
decrease the net calcification rates (aragonite formation) of stony corals (Silverman et al., 2009; Rodolfo-Metalpa et al., 2011). Furthermore, the coral reefs of the North Red Sea attract thousands of visitors that can contribute to impacts on coral reefs (Hasler \& Ott, 2008). Submerged marine litter in coral reefs of the North Red Sea with an overall mean density of 2.8 items $/ \mathrm{m}^{2}$ and overall mean weight of $0.31 \mathrm{~kg} / \mathrm{m}^{2}$ is another major concern (Abu-Hilal \& Al-Najjar, 2009). Bioaccumulation of toxic contaminants in North Red Sea corals is high (Ali et al., 2010). Moreover, coastal development has resulted in increasing demand for freshwater. Seawater desalination plants are being constructed that discharge high salinity water often contaminated with other chemicals (Hoepner \& Lattemann, 2003).

The Mediterranean coasts support a high density of inhabitants, distributed in 21 countries with a population of about 450 million (cf. 246 million in 1960), of which 132 million live on the coast (26,000 km in length). In addition, 200 million tourists per year visit Mediterranean coastal countries. During the past one hundred years, the Eastern Mediterranean has been subjected to the effects of two important events, the opening of the Suez Canal in 1869 (discussed below) and the construction of the Aswan High Dam in 1964. Before the construction of the High Dam, nutrient enrichment extended along the Egyptian coast and was detected off the Israeli coast and sometimes off southern Turkey. It provided for dense blooms of phytoplankton off the Nile Delta (Nile bloom) which in turn provided nourishment to sardines, other pelagic fishes and crustaceans. Huge declines have been observed in these fisheries in the years following the High Dam construction. Since the late 1980s the recovery of total fish landings in the region reveal that the pelagic ecosystem is adjusting but the mismatch between extremely low primary productivity and relatively high levels of fish production remains a puzzle 'the Levantine Basin Paradox' to scientists (Dasgupta \& Chattopadhyay, 2004). Whether this recent increase in fisheries is due to increased fishing efforts, recovery of fish stocks or nutrient enrichments by anthropogenic activities is not yet clear.

Human activities have been reducing biodiversity of the Mediterranean Sea at all levels. The major stressors in the Eastern Mediterranean appear to be: climate change, alien species invasions, pollution, fishing impacts, eutrophication and aquaculture, and habitat loss (Claudet \& Fraschetti, 2010; Coll et al., 2010; Durrieu de Madron et al., 2011). Often these stressors act synergistically and have cumulative negative impacts on a great number of taxonomic groups. The Mediterranean Sea is perhaps the most investigated marine environment in the world, however research efforts have been concentrated in the northwestern Mediterranean, so much less is known about human-environmental interaction in the ultraoligotrophic waters of southeastern Mediterranean.

\section{Climate change}

The effects of global climate change are likely to affect chemical and physical properties of the water and act synergistically with other anthropogenic stressors (Gambaiani et al., 2009). Climate change impacts in the Mediterranean may provide useful insights for potential impacts elsewhere as the region is well monitored. As in many other regions; sea temperatures are rising, acidification is underway, extreme climatic events and related disease outbreaks are becoming more frequent, native species are being displaced and invasive species are spreading (Lejeusne et al., 2010). 
Increased warming across the Mediterranean increases stratification of the water column further restricting nutrient availability in ultraoligotrophic zones and is related to increased mortality of the endemic seagrass Posidonia oceanica (Diaz-Almela et al., 2009). Higher temperatures may disrupt juvenile life histories stages of numerous organisms (Hawkes et al., 2007; Byrne, 2011) and cause mass mortalities of adults (Garrabou et al., 2009). In addition increasing temperatures may also contribute to higher frequencies of disease outbreaks as tropical microbial pathogens are expected to spread (Danovaro et al., 2009). Rising water temperatures are altering biogeographic boundaries and leading to a progressive homogenization of Mediterranean marine biota. Changes include an increase in abundance of eurythermal species and a decrease in cold stenothermal species as well as northward species shifts and mass mortalities during unusually hot summers (Coll et al., 2010). Warm-water fish like Thalassoma pavo, Sphyraena spp., Epinephelus spp., Sparisoma cretense and, Sardinella aurita have spread northwestwards (Sara et al., 2005). Certain cold water species have been replaced, for example the distribution of the cave-dwelling crustacean Hemimysis speluncola has contracted and been replaced by H. margalefi, a warm water species that was previously unknown in the region (Chevaldonné \& Lejeusne, 2003). Non-indigenous warm water species of algae, invertebrates and fish are enlarging their geographical ranges (Bianchi, 2007). Invasive tropical fauna and flora are most evident in the southern Mediterranean where they now form a significant portion of the biota and some outcompete native species (Lasram \& Mouillot, 2009). Predicted levels of warming for the end of this century lie beyond the thermotolerance levels of the developmental stages of many metazoa (Byrne, 2011).

Ocean acidification may also alter the ecology of the Mediterranean, although the evidence to date is sparse. Israel and Hophy (2002), found that acidifying seawater to $\mathrm{pH} 7.8$ with $\mathrm{CO}_{2}$ did not adversely affect growth and photosynthesis in a wide range of Mediterranean chlorophyte, rhodophyte and phaeophyte algae whereas Invers et al. (1997) found that this level of acidification enhanced photosynthesis in the Mediterranean seagrasses Posidonia oceanica and Cymodocea nodosa. Martin and Gattuso (2009) found that the Mediterranean encrusting coralline alga Lithophyllum cabiochae decreased calcification when elevated $p \mathrm{CO}_{2}$ conditions were combined with high temperatures $\left(\mathrm{pH} 7.8\right.$; seasonal temperature $+3^{\circ} \mathrm{C}$ ). Investigations into the effects of acidification at a natural volcanic $\mathrm{CO}_{2}$ vent off Ischia in Italy show that seagrasses and certain seaweeds were able to benefit from the elevated $\mathrm{CO}_{2}$ levels (Martin et al., 2008; Porzio et al., 2011) but that around 30\% of the coastal biodiversity was lost at mean $\mathrm{pH}$ levels predicted for 2100 (Hall-Spencer et al., 2008). This is partly because ocean acidification disrupts recruitment of organisms from the plankton (Cigliano et al., 2010), and partly because peak summer temperatures increase the susceptibility of some organisms to shell and skeleton dissolution (Rodolfo-Metalpa et al., 2011). Calcareous systems such as vermetid reefs and, mussel beds, as well as deep and shallow coral communities, appear to be especially vulnerable in ultraoligotrophic regions where organisms lack food and are therefore less able to allocate resources for coping with multiple stressors. In contrast, carbon limited organisms, like seagrasses, may make use of the extra dissolved $\mathrm{CO}_{2}$ and if their habitats are protected they may thrive due to higher photosynthetic rates.

\section{Alien species}

Warm-water species are found in the Mediterranean due to Atlantic influx, Lessepsian migration, introductions by humans and present-day sea warming (Bianchi, 2007). Most of 
the 955 alien species so far recorded occur in the oligotrophic Eastern Mediterranean (Zenetos et al., 2010). About $20 \%$ of Mediterranean alien species were accidentally introduced from biofouling on ship hulls or in ballast tanks (Galil, 2009). However most (about $67 \%$ ) Mediterranean alien species came from the Red Sea since the Suez Canal was opened in 1869. More than 600 tropical Indo-Pacific species have been reported entering the Mediterranean where they have established reproducing populations in the Levantine basin and beyond (Coll et al., 2010; Costello et al., 2010). The rate of invasion of species from the Red Sea into the low nutrient waters of the eastern Mediterranean is increasing due to warming. Now nearly half of the trawl catches along the Levantine coast consist of Erythrean fish, but whilst some are now targeted commercially, others are detrimental to fisheries. In Cyprus, for example, the invasive puffer fish Lagocephalus sceleratus is outcompeting native fishes and exhausting invertebrates such as the Octopus vulgaris and squid; in this region several other invasive species have caused substantial shifts in coastal ecosystems (Katsanevakis et al., 2009).

\section{Pollution}

Like all coastal systems the Mediterranean Sea is affected by numerous anthropogenic contaminants, but due to its enclosed and oligotrophic nature their impacts can be exacerbated. Marine litter is a major problem in the region, causing obstruction of digestive tracts and contaminant bioaccumulation in many marine animals. Persistent organic pollutants tend to bioaccumulate and come from maritime sources, aerosol deposits, urban/industrial activity, river discharges and accumulate in harbour sediments (GómezGutiérrez et al., 2007; Thébault et al., 2008).

Riverine inputs and air masses from northern and central Europe carry persistent organic pollutants that can reach the Eastern Mediterranean basin (Mandalakis \& Stephanou, 2002). Large commercial harbours are situated mostly in the northwest Mediterranean and maritime traffic causes noise pollution that adversely affects cetaceans (Dolman et al., 2011). Submarine drilling for oil and gas takes place in the south with exploration now underway in the eastern Mediterranean. About 300000 tonnes of crude oil are released into the Mediterranean every year (Danovaro \& Pusceddu, 2007) and can cause environmental damage, especially when chemical dispersants are used in clean-up procedures. An oil spill in Valencia in 1990 was followed by hundreds of dead dolphins being washed up along the Spanish, French, Italian and North African shores and a year later on the beaches of southern Italy and Greece, thought to be due to disease triggered by immunosuppressants in the oil spill (Zenetos et al., 2002).

\section{Overexploitation of resources}

Industrialized fishing has severe impacts on species, habitats and ecosystems (Tudela, 2004). Several fish resources are highly exploited or overexploited (Palomera et al., 2007; MacKenzie et al., 2009). A number of other organisms are also affected by exploitation and include unwanted by-catch (accidental capture in fishing gear). Bottom-trawling is a nonselective fishing method and causes a large mortality of discarded benthic invertebrates which can induce severe biodiversity and biogeochemical changes (Pusceddu et al., 2005). Severe population declines have occurred for all top predators during the last 50 years with the Mediterranean Sea described as the most dangerous sea in the world for cartilaginous fishes (Cavanagh \& Gibson, 2007). See turtles face entangling, pollution and loss of habitat. 
Population declines have also been recorded among marine mammals (such as sperm whales, short-beaked common dolphins, common bottlenose dolphins, striped dolphins and monk seals) that face prey depletion, direct killing and fishery by-catch (Reeves \& Notarbartolo, 2006). The Mediterranean monk seal is the most endangered seal in the world with less than 600 individuals currently surviving. Remnant populations are fragmented and declining. The species faces a number of threats (i.e. accidental entanglement, exploitation, persecution and tourism) that caused severe declines in abundance (Karamanlidis et al., 2008).

There are clearly multiple threats acting synergistically on species of the Mediterranean Sea. For example, in December 2009, a pod of seven male sperm whales stranded along the coasts of Southern Italy. It appears the cause of death was prolonged starvation not from plastic obstruction (even though plastic was found in all dissected individuals) but due to a lack of prey. High concentrations of pollutants in the tissues of the stranded animals led researchers to conclude that prolonged starvation stimulated the mobilization of highly concentrated lipophilic contaminants from their adipose tissue which entered the blood circulation and may have impaired immune and nervous functions (Mazzariol et al., 2011).

\section{Eutrophication and aquaculture}

Eutrophication in the ultraoligotrophic Eastern Mediterranean is disrupting habitats and causing community shifts. Eutrophic conditions favour opportunistic species that may increase productivity and fishery catches but may out compete the highly diverse communities of ultraoligotrophic systems. Eutrophication sources from agriculture, urbanization, river run-offs, and aquaculture. Considering the exponential human population growth and the fact that fisheries are in global decline, aquaculture efforts are predicted to increase to meet growing demand (Duarte et al., 2009).

Fin-fish farming can have a number of environmental effects on the surrounding and downstream ecosystems (Holmer et al., 2008). Dissolved wastes increase the nutrient loading of the area and particulate wastes increase sediment deposition. In the benthos sedimentation and organic loading can cause biochemical changes affecting the composition and function of benthic communities (Karakassis et al., 2000), stimulating the growth of undesirable species that produce toxic metabolic waste that can kill species of conservation significance. Large-scale Posidonia oceanica losses adjacent to fish farm cages have been reported across the Mediterranean (Pergent-Martini et al., 2006) including the Eastern Mediterranean (Holmer et al., 2008; Apostolaki et al., 2009).

Improved fish farm management may increase their sustainability although culturing carnivorous fish is still likely to come at environmental costs. Integrated multi-trophic aquaculture (culturing organisms from different trophic levels, mimicking natural ecosystem interactions and producing less waste than monoculture systems) may be key to environmental sustainability of aquaculture practices in ultraoligotrophic waters (Chopin, 2006; Angel \& Freeman, 2009).

\section{Habitat loss}

Coastal habitats such as seagrass meadows, mollusc (oyster, vermetid and mussel) reefs, coralligenous maerl formations, and macroalgal assemblages on shallow reefs are examples of complex and highly productive ecosystems. They supply food resources, nurseries and 
shelter for a large array of species that are protected by international conventions, directives and action plans. A meta-analysis of 158 experiments in the Mediterranean revealed that human activity caused adverse impacts on all habitat types. Fisheries, species invasion, aquaculture, sedimentation increase, water degradation, and urbanization can all have negative impacts on Mediterranean habitats and associated species assemblages (Claudet \& Fraschetti, 2010).

Habitat destruction is considered one of the most pervasive threats to the diversity, structure and functioning of marine coastal ecosystems. The loss of habitat structure generally leads to lower abundances and species richness that usually allows opportunistic species to prosper (Airoldi et al., 2008). Habitat destruction can also impair the integrity, connectivity and functioning of large-scale processes decreasing population stability and isolating communities (Thrush et al., 2006). Continued losses of habitats to coastal development has triggered several international protective measures such as the development of Marine Protected Areas (MPAs), but their efficacy is much questioned (García-Charton et al., 2008; Montefalcone et al., 2009) as habitat loss continues apace.

Oligotrophic coastal habitats are dominated by slow growing species and intricate food webs. Habitat losses can be considered irreversible, as it would take centuries following the cessation of disturbances for ecosystems to return to their climax state.

\section{Conclusions}

Ultraoligotrophic marine ecosystems cover almost a third of the earth's surface and contribute significantly to global productivity and biogeochemistry. They are, however, amongst the least understood systems on this planet. Once considered to be monotonous oceanic desserts, they are now known to have highly dynamic physical and biological properties with extremely diverse and vertically-distinct planktonic communities.

There is increasing evidence that these systems may be net autotrophic. The water column is dominated by the smallest eukaryotic and prokaryotic picoplankton, which seem well adapted for surviving in oligotrophic conditions. Adaptations range from niche segregation through prolonged coexistence, symbiotic associations, mixed modes of nutrition, lower cellular nutrient requirements, genes encoding for enzymes that regenerate nutrients from allochthonous sources, genes involved in high affinity uptake of nutrients and efficient nutrient uptake due to large surface: volume ratios. Unicellular cyanobacteria and extremely diverse picoeukaryotes dominate primary production in the deep euphotic zones of ultraoligotrophic waters. This production is channelled through the microbial food web (e.g. small ciliates and nanoflagellates) to vertically-migrating gelatinous and crustacean zooplankton and then to higher trophic levels. Phytoplankton blooms mainly occur after winter mixing events but sporadic blooms can occur during the stratified periods. Such blooms can favour larger planktonic species that in turn may sustain large predators (e.g. leatherback turtles, elasmobranchs, cetaceans, tunas and billfishes).

Environmental metagenomics has revealed the high biodiversity observed in ultraoligotrophic marine systems, although the causes for this high biodiversity remain puzzling (Roy \& Chattopadhyay, 2007). In the Eastern Mediterranean and North Red Sea biogenic engineers such as corals, seagrasses, and macroalgae form habitats that are biodiversity hotspots of international commercial significance. Exponential growth in the 
human population has resulted in multiple stressors that act synergistically in the marine environment reducing biodiversity. We believe that in ultraoligotrophic environments, where resources are scarce, organisms are particularly vulnerable to multiple stressors. Climate change is underway and its impacts may continue for many millennia after cessation of anthropogenic $\mathrm{CO}_{2}$ emissions (Tyrrell, 2011). Warming increases stratification that keeps nutrients below the thermocline. Deoxygenated regions are expanding and acidification may impair ecological functioning (Byrne, 2011). Predictions for 2100 include substantial changes in biogeochemical processes and the extinction of many tropical coral reefs (Silverman et al., 2009). In addition to climate change, marine litter continues to accumulate in ultraoligotrophic subtropical gyres where it is physically degraded to microscopic pieces adsorbing persistent organic contaminants from the surrounding water. Plastic has been found in many consumer species ranging from copepods to large mammals. It may cause starvation, contaminant bioaccumulation, alien species transportation and entanglement. Enclosed ultraoligotrophic systems face additional threats due to their close proximity to Man. Toxic pollutants bioaccumulate and impair the normal physiological functions of organisms causing for example, cetacean strandings. Invasive alien species are spreading and are competing, predating and infecting indigenous species and altering ancient food webs. Marine fish stocks are overexploited with most top predators in decline. Eutrophication decreases water quality which can add pressure on coastal systems subjected to habitat loss and degradation. It is clear that past methods have failed to ensure environmental sustainability yet there are several reasons to be optimistic.

It is now realized that marine ecosystem degradation is a global concern. International efforts to reduce rates of biodiversity loss have led to numerous agreements, conventions or other legal instruments that are coming into force. Such international agreements form the basis of long-term collaboration that is necessary for improved environmental management. For example, the Kyoto Protocol came into force on 2005 and commits the 191 member states to tackle the issue of global warming by reducing greenhouse gas emissions. Annex 1 countries pledged to reduce their emissions by $5.2 \%$ from 1990 levels by the end of 2012. The United Nations Convention on the Law of the Sea (UNCLOS) signed by 161 countries helps control pollution and set guidelines for the protection of the environment and the management of marine natural resources in the world's oceans. Inter-governmental organizations, like the International Commission for the Conservation of Atlantic Tunas (ICCAT), are charged with the conservation of stocks of highly migratory species. In Europe, the Marine Strategy Framework Directive aims to achieve healthy waters by 2020 with an unprecedented level of cooperation between countries in developing a network of MPAs. Monitoring of environmental quality, biodiversity and long-term changes in community structure through an international coordinated network of MPAs is an approaching reality. Cautious use of Integrated Coastal Zone Management and Environmental Impact Assessments can help slow the rate of coastal environmental degradation. International partnerships like the Global Ocean Biodiversity Initiative (GOBI) are promising and the identification of Ecologically or Biologically Significant Areas (EBSAs) in the open oceans and deep seas is well underway. It is clear that these international efforts are required to slow the rates of marine environmental degradation.

There are now ample examples where interventions have had positive environmental outcomes. A primary goal among nations should be to raise awareness of effective marine environmental protection. For example, the most viable option to reduce litter is to reduce 
its production in the first place and then to improve reuse and recycling through enhanced environmental awareness (Thiel et al., 2011). There is now scientific clarity that ocean warming, acidification and deoxygenation are underway due to $\mathrm{CO}_{2}$ emissions so the primary mitigation strategy is to reduce these emissions (Gruber, 2011). There are reasons to be optimistic about improved management of ultraoligotrophic systems as a growing awareness of their value is being accompanied by shifts towards more sustainable ways of obtaining resources (e.g. marine renewables) and dealing with wastes (e.g. carbon capture and storage).

Change is underway...

\section{Acknowledgment}

This review is a contribution to the EU Framework 7 Program funded by MedSeA grant 265103 (Mediterranean acidification under a changing climate) and KnowSeas grant 226675 (Knowledge-based Sustainable Management for Europe's Seas). The European Mediterranean Sea Acidification in a changing climate (MedSeA) http://medseaproject.eu/.

\section{References}

Aberle, N.; Hansen, T.; Boettger-Schnack, R.; Burmeister, A.; Post, A.\&Sommer, U., (2010). Differential routing of "new" nitrogen toward higher trophic levels within the marine food web of the Gulf of Aqaba, Northern Red Sea. Marine Biology Vol. 157, No. 1, pp. (157-169), 1432-1793

Abu-Hilal, A.\&Al-Najjar, T., (2009). Marine litter in coral reef areas along the Jordan Gulf of Aqaba, Red Sea. Journal of Environmental Management Vol. 90, No. 2, pp. (1043-1049), 0301-4797

Airoldi, L.; Balata, D.\&Beck, M.W., (2008). The Gray Zone: Relationships between habitat loss and marine diversity and their applications in conservation. Journal of Experimental Marine Biology and Ecology Vol. 366, No. 1-2, pp. (8-15), 0022-0981

Aktan, Y., (2011). Large-scale patterns in summer surface water phytoplankton (except picophytoplankton) in the Eastern Mediterranean. Estuarine, Coastal and Shelf Science Vol. 91, No. 4, pp. (551-558), 0272-7714

Al-Najjar, T.; Badran, M.; Richter, C.; Meyerhoefer, M.\&Sommer, U., (2007). Seasonal dynamics of phytoplankton in the Gulf of Aqaba, Red Sea. Hydrobiologia Vol. 579, No. 1, pp. (69-83), 1573-5117

Ali, A.-h.; Hamed, M.\&Abd El-Azim, H., (2010). Heavy metals distribution in the coral reef ecosystems of the Northern Red Sea. Helgoland Marine Research Vol. 65, No. 1, pp. (67-80), 1438-3888

Andersen, N.G.; Nielsen, T.G.; Jakobsen, H.H.; Munk, P.\&Riemann, L., (2011). Distribution and production of plankton communities in the subtropical convergence zone of the Sargasso Sea. II. Protozooplankton and copepods. Marine Ecology Progress Series Vol. 426, No. pp. (71-86), 1616-1599

Angel, D.\&Freeman, S., (2009). Integrated aquaculture (INTAQ) as a tool for an ecosystem approach in the Mediterranean Sea. FAO Fisheries and Aquaculture Technical Paper Vol. 529, No. pp. (133-183), 2070-7010 
Apostolaki, E.T.; MarbГ , N.; Holmer, M.\&Karakassis, I., (2009). Fish farming enhances biomass and nutrient loss in Posidonia oceanica (L.) Delile. Estuarine, Coastal and Shelf Science Vol. 81, No. 3, pp. (390-400), 0272-7714

Ballesteros, E., (2006). Mediterranean coralligenous assemblages : A synthesis of present knowledge. Anglais Vol. 44, No. (0078-3218), pp. (123-196), 0078-3218

Barcelos e Ramos, J.; Biswas, H.; Schulz, K.G.; LaRoche, J.\&Riebesell, U., (2007). Effect of rising atmospheric carbon dioxide on the marine nitrogen fixer Trichodesmium. Global Biogeochemical Cycles Vol. 21, No. 2, pp. (GB2028), 0886-6236

Bas, C., (2009). The Mediterranean: a synoptic overview Contributions to Science Vol. 5, No. 1, pp. (25-39), 1575-6343

Beaufort, L.; Couapel, M.; Buchet, N.; Claustre, H.\&Goyet, C., (2008). Calcite production by coccolithophores in the south east Pacific Ocean. Biogeosciences Vol. 5, No. 4, pp. (1101-1117), 1726-4189

Beaufort, L.; Probert, I.; de Garidel-Thoron, T.; Bendif, E.M.; Ruiz-Pino, D.; Metzl, N., et al., (2011). Sensitivity of coccolithophores to carbonate chemistry and ocean acidification. Nature Vol. 476, No. 7358, pp. (80-83), 0028-0836

Beman, J.M.; Chow, C.-E.; King, A.L.; Feng, Y.; Fuhrman, J.A.; Andersson, A., et al., (2011). Global declines in oceanic nitrification rates as a consequence of ocean acidification. Proceedings - National Academy Of Sciences USA Vol. 108, No. 1, pp. (208-213), 10916490

Berninger, U.-G.\&Wickham, S.A., (2005). Response of the microbial food web to manipulation of nutrients and grazers in the oligotrophic Gulf of Aqaba and northern Red Sea. Marine Biology Vol. 147, No. 4, pp. (1017-1032), 1432-1793

Bianchi, C.N., (2007). Biodiversity issues for the forthcoming tropical Mediterranean Sea. Hydrobiologia Vol. 580, No. 1, pp. (7-21), 0018-8158

Bianchi, C.N.\&Morri, C., (2000). Marine Biodiversity of the Mediterranean Sea: Situation, Problems and Prospects for Future Research. Marine Pollution Bulletin Vol. 40, No. 5, pp. (367-376), 0025-326X

Bonnet, S.; Grosso, O.\&Moutin, T., (2011). Planktonic dinitrogen fixation in the Mediterranean Sea: a major biogeochemical process during the stratified period? Biogeosciences Discuss Vol. 8, No. 1, pp. (1197-1225), 1810-6285

Bonnet, S.; Guieu, C.; Bruyant, F.; Prášil, O.; Van Wambeke, F.; Raimbault, P., et al., (2008). Nutrient limitation of primary productivity in the Southeast Pacific (BIOSOPE cruise). Biogeosciences Vol. 5, No. 1, pp. (215-225), 1726-4189

Bryant, D.A., (2003). The beauty in small things revealed. Proceedings - National Academy Of Sciences USA Vol. 100, No. 17, pp. (9647-9649), 0027-8424

Byrne, M., (2011). Impact of ocean warming and ocean acidification on marine invertebrate life history stages: Vulnerabilities and potential for persistence in a changing ocean, in: Oceanography and Marine Biology: An Annual Review, R. N. Gibson, R. J. A. Atkinson, J. D. M. Gordon, I. P. Smith and D. J. Hughes (Editors), pp. (1-42), CRC Press, 978-1-4398536-4-1,

Calbet, A., (2008). The trophic roles of microzooplankton in marine systems. ICES Journal of Marine Science: Journal du Conseil Vol. 65, No. 3, pp. (325-331), 1054-3139

Cantin, N.E.; Cohen, A.L.; Karnauskas, K.B.; Tarrant, A.M.\&McCorkle, D.C., (2010). Ocean Warming Slows Coral Growth in the Central Red Sea. Science Vol. 329, No. 5989, pp. (322-325), 1095-9203 
Capone, D.G.; Zehr, J.P.; Paerl, H.W.; Bergman, B.\&Carpenter, E.J., (1997). Trichodesmium, a Globally Significant Marine Cyanobacterium. Science Vol. 276, No. 5316, pp. (12211229), 0036-8075

Cavanagh, R.D.\&Gibson, C., (2007). Overview of the conservation status of cartilaginous fishes (Chondrichthyans) in the Mediterranean Sea, The World Conservation Union (IUCN), 978-2-8317-0997-0, Gland, Switzerland and Malaga, Spain.

Cermeño, P.\&Figueiras, F.G., (2008). Species richness and cell-size distribution: size structure of phytoplankton communities. Marine Ecology Progress Series Vol. 357, No. pp. (79-85), 0171-8630

Chevaldonné, P.\&Lejeusne, C., (2003). Regional warming-induced species shift in northwest Mediterranean marine caves. Ecology Letters Vol. 6, No. 4, pp. (371-379), 14610248

Chopin, T., (2006). Integrated Multi-Trophic Aquaculture. What it is and why you should care... and don't confuse it with polyculture. Northern Aquaculture Vol. 12, No. 4, pp. (4), 1183-2428

Christaki, U.; Courties, C.; Karayanni, H.; Giannakourou, A.; Maravelias, C.; Kormas, K.A., et al., (2002). Dynamic Characteristics of Prochlorococcus and Synechococcus Consumption by Bacterivorous Nanoflagellates. Microbial Ecology Vol. 43, No. 3, pp. (341-352), 1432-184X

Church, M.J.; Mahaffey, C.; Letelier, R.M.; Lukas, R.; Zehr, J.P.\&Karl, D.M., (2009). Physical forcing of nitrogen fixation and diazotroph community structure in the North Pacific subtropical gyre. Global Biogeochem. Cycles Vol. 23, No. 2, pp. (GB2020), 08866236

Cigliano, M.; Gambi, M.; Rodolfo-Metalpa, R.; Patti, F.\&Hall-Spencer, J., (2010). Effects of ocean acidification on invertebrate settlement at volcanic $\mathrm{CO}_{2}$ vents. Marine Biology Vol. 157, No. 11, pp. (2489-2502), 1432-1793

Claessens, M.; Wickham, S.A.; Post, A.F.\&Reuter, M., (2008). Ciliate community in the oligotrophic Gulf of Aqaba, Red Sea. Aquatic Microbial Ecology Vol. 53, No. 2, pp. (181-190), 1616-1564

Claudet, J.\&Fraschetti, S., (2010). Human-driven impacts on marine habitats: A regional meta-analysis in the Mediterranean Sea. Biological Conservation Vol. 143, No. 9, pp. (2195-2206), 0006-3207

Claustre, H.; Huot, Y.; Obernosterer, I.; Gentili, B.; Tailliez, D.\&Lewis, M., (2008 ). Gross community production and metabolic balance in the South Pacific Gyre, using a non intrusive bio-optical method. Biogeosciences Vol. 5, No. 2, pp. (463-474), 17264189

Coll, M.; Piroddi, C.; Steenbeek, J.; Kaschner, K.; Ben Rais Lasram, F.; Aguzzi, J., et al., (2010). The biodiversity of the mediterranean sea: estimates, patterns, and threats. PLoS One Vol. 5, No. 8, (eng), pp. (e11842-e11842), 1932-6203

Costello, M.J.; Coll, M.; Danovaro, R.; Halpin, P.; Ojaveer, H.\&Miloslavich, P., (2010). A Census of Marine Biodiversity Knowledge, Resources, and Future Challenges. PLoS ONE Vol. 5, No. 8, pp. (e12110), 1932-6203

Czerny, J.; Barcelos e Ramos, J.\&Riebesell, U., (2009). Influence of elevated $\mathrm{CO}_{2}$ concentrations on cell division and nitrogen fixation rates in the bloom-forming cyanobacterium Nodularia spumigena. Biogeosciences Discussions Vol. 6, No. 2, pp. (4279-4304), 1810-6285 
D'Ortenzio, F.\&Ribera d'Alcalà, M., (2009). On the trophic regimes of the Mediterranean Sea: a satellite analysis. Biogeosciences Vol. 6, No. 2, pp. (139-148), 1726-4189

Danovaro, R.; Fonda Umani, S.\&Pusceddu, A., (2009). Climate Change and the Potential Spreading of Marine Mucilage and Microbial Pathogens in the Mediterranean Sea. PLoS ONE Vol. 4, No. 9, pp. (e7006), 1932-6203

Danovaro, R.\&Pusceddu, A., (2007). Ecomanagement of biodiversity and ecosystem functioning in the Mediterranean Sea: concerns and strategies. Chemistry and Ecology Vol. 23, No. 5, pp. (347-360), 1029-0370

Dasgupta, T.\&Chattopadhyay, R.N., (2004). Ecological Contradictions Through Ages: Growth and Decay of the Indus and Nile Valley Civilizations. Journal of Human Ecology Vol. 16, No. 3, pp. (197-201), 0970-9274

Dave, A.C.\&Lozier, M.S., (2010). Local stratification control of marine productivity in the subtropical North Pacific. J. Geophys. Res. Vol. 115, No. C12, pp. (C12032), 0148-0227

Davison, P.\&Asch, R.G., (2011). Plastic ingestion by mesopelagic fishes in the North Pacific Subtropical Gyre. Marine Ecology Progress Series Vol. 432, No. pp. (173-180), 16161599

Dekas, A.E.; Poretsky, R.S.\&Orphan, V.J., (2009). Deep-Sea Archaea Fix and Share Nitrogen in Methane-Consuming Microbial Consortia. Science Vol. 326, No. 5951, pp. (422426), 1095-9203

DeLong, E.F., (2009). The microbial ocean from genomes to biomes. Nature Vol. 459, No. 7244, pp. (200-206), 0028-0836

Denis, M.; Thyssen, M.; Martin, V.; Manca, B.\&Vidussi, F., (2009). Ultraphytoplankton distribution and upper ocean dynamics in the eastern Mediterranean during winter. Biogeosciences Discuss Vol. 6, No. 4, pp. (6839-6887), 1810-6285

Denman, K.; Christian, J.R.; Steiner, N.; Pörtner, H.-O.\&Nojiri, Y., (2011). Potential impacts of future ocean acidification on marine ecosystems and fisheries: current knowledge and recommendations for future research. ICES Journal of Marine Science: Journal du Conseil Vol. 68, No. 6, pp. (1019-1029), 1095-9289

Denuncio, P.; Bastida, R.; Dassis, M.; Giardino, G.; Gerpe, M.\&Rodríguez, D., (2011). Plastic ingestion in Franciscana dolphins, Pontoporia blainvillei (Gervais and d'Orbigny, 1844), from Argentina. Marine Pollution Bulletin Vol. 62, No. 8, pp. (1836-1941), 0025326X

Diaz-Almela, E.; Marba, N.; Martinez, R.; Santiago, R.\&Duarte, C., M., (2009). Seasonal dynamics of Posidonia oceanica in Magalluf Bay (Mallorca, Spain): Temperature effects on seagrass mortality. Limnology and Oceanography Vol. 54, No. 6, (00243590), pp. (2170-2182), 1939-5590

Dolan, J.R.; Ritchie, M.E.\&Ras, J., (2007). The "neutral" community structure of planktonic herbivores, tintinnid ciliates of the microzooplankton, across the SE Tropical Pacific Ocean. Biogeosciences Vol. 4, No. 3, pp. (297-310), 1726-4189

Dolman, S.J.; Evans, P.G.H.; Notarbartolo-di-Sciara, G.\&Frisch, H., (2011). Active sonar, beaked whales and European regional policy. Marine Pollution Bulletin Vol. 63, No. 1-4, pp. (27-34), 0025-326X

Doney, S.C., (2010). The Growing Human Footprint on Coastal and Open-Ocean Biogeochemistry. Science Vol. 328, No. 5985, pp. (1512-1516), 1095-9203

Dore, J.E.; Letelier, R.M.; Church, M.J.; Lukas, R.\&Karl, D.M., (2008). Summer phytoplankton blooms in the oligotrophic North Pacific Subtropical Gyre: 
Historical perspective and recent observations. Progress In Oceanography Vol. 76, No. 1, pp. (2-38), 0079-6611

Duarte, C.; Holmer, M.; Olsen, Y.; Soto, D.; Marbà, N.; Guiu, J., et al., (2009). Will the oceans help feed humanity? BioScience Vol. 59, No. 11, pp. (967-976), 0006-3568

Duarte, C.M., (1991). Seagrass depth limits. Aquatic Botany Vol. 40, No. 4, pp. (363-377), 03043770

Duhamel, S.; Dyhrman, S.T.\&Karl, D.M., (2011). Alkaline phosphatase activity and regulation in the North Pacific Subtropical Gyre. Limnology and Oceanography Vol. 55, No. 3, (0024-3590), pp. (1414-1425), 1939-5590

Durrieu de Madron, X.; Guieu, C.; Sempéré, R.; Conan, P.; Cossa, D.; D $€^{\mathrm{TM} O r t e n z i o, ~ F ., ~ e t ~}$ al., (2011). Marine ecosystems' responses to climatic and anthropogenic forcings in the Mediterranean. Progress In Oceanography Vol. 91, No. 2, pp. (97-166), 0079-6611

Dyhrman, S.T.; Ammerman, J.W.\&Van Mooy, B.A.S., (2009). Microbes and the Marine Phosphorus Cycle. Oceanography Vol. 20, No. 2, pp. (110-116), 1042-8275

Eden, B.R.; Steinberg, D.K.; Goldthwait, S.A.\&Mcgillicuddy, D.J., (2009). Zooplankton community structure in a cyclonic and mode-water eddy in the Sargasso Sea. Deep Sea Research Part I: Oceanographic Research Papers Vol. 56, No. 10, pp. (1757-1776), 0967-0637

Eiler, A.; Hayakawa, D.H.\&Rapp?, M.S., (2011). Non-random assembly of bacterioplankton communities in the subtropical North Pacific Ocean. Frontiers in Microbiology Vol. 2, No. 140, (English), pp. (1-12), 1664-302X

Field, C.B.; Behrenfeld, M.J.; Randerson, J.T.\&Falkowski, P., (1998). Primary Production of the Biosphere: Integrating Terrestrial and Oceanic Components. Science - New York then Washington Vol. 281, No. 5374, pp. (237-240), 0036-8075

Fong, A.A.; Karl, D.M.; Lukas, R.; Letelier, R.M.; Zehr, J.P.\&Church, M.J., (2008). Nitrogen fixation in an anticyclonic eddy in the oligotrophic North Pacific Ocean. ISME J Vol. 2, No. 6, pp. (663-676), 1751-7370

Foster, R.A.; Paytan, A.\&Zehr, J.P., (2009). Seasonality of $\mathrm{N}_{2}$ fixation and nifH gene diversity in the Gulf of Aqaba (Red Sea). Limnology and Oceanography Vol. 54, No. 1, pp. (219233), 1939-5590

Fricke, H.W.\&Schuhmacher, H., (1983). The Depth Limits of Red Sea Stony Corals: An Ecophysiological Problem (A Deep Diving Survey by Submersible). Marine Ecology Vol. 4, No. 2, pp. (163-194), 1616-1599

Fu, F.-X.; Mulholland, M.R.; Garcia, N.S.; Beck, A.; Bernhardt, P.W.; Warner, M.E., et al., (2008). Interactions between changing pCO sub(2), N sub(2) fixation, and Fe limitation in the marine unicellular cyanobacterium Crocosphaera. Limnology and Oceanography Vol. 53, No. 6, pp. (2472-2484), 1939-5590

Galil, B., (2009). Taking stock: inventory of alien species in the Mediterranean sea. Biological Invasions Vol. 11, No. 2, pp. (359-372), 1573-1464

Gambaiani, D.D.; Mayol, P.; Isaac, S.J.\&Simmonds, M.P., (2009). Potential impacts of climate change and greenhouse gas emissions on Mediterranean marine ecosystems and cetaceans. Journal of the Marine Biological Association of the United Kingdom Vol. 89, No. 01, pp. (179-201), 1469-7769

García-Charton, J.A.; Pérez-Ruzafa, A.; Marcos, C.; Claudet, J.; Badalamenti, F.; BenedettiCecchi, L., et al., (2008). Effectiveness of European Atlanto-Mediterranean MPAs: 
Do they accomplish the expected effects on populations, communities and ecosystems? Journal for Nature Conservation Vol. 16, No. 4, pp. (193-221), 1617-1381

Garrabou, J.; Coma, R.; Bensoussan, N.; Bally, M.; ChevaldonnÉ, P.; Cigliano, M., et al., (2009). Mass mortality in Northwestern Mediterranean rocky benthic communities: effects of the 2003 heat wave. Global Change Biology Vol. 15, No. 5, pp. (1090-1103), 1365-2486

Gist, N.; Serret, P.; Woodward, E.M.S.; Chamberlain, K.\&Robinson, C., (2009). Seasonal and spatial variability in plankton production and respiration in the Subtropical Gyres of the Atlantic Ocean. Deep Sea Research Part II: Topical Studies in Oceanography Vol. 56, No. 15, pp. (931-940), 0967-0645

Goffart, A.; Hecq, J.H.\&Legendre, L., (2002). Changes in the development of the winterspring phytoplankton bloom in the Bay of Calvi (NW Mediterranean) over the last two decades: a response to changing climate? Marine Ecology Progress Series Vol. 236, No. 45-60, pp. 0171-8630

Gómez-Gutiérrez, A.; Garnacho, E.; Bayona, J.M.\&Albaigés, J., (2007). Assessment of the Mediterranean sediments contamination by persistent organic pollutants. Environmental Pollution Vol. 148, No. 2, pp. (396-408), 0269-7491

Gómez, F., (2007). On the consortium of the tintinnid Eutintinnus and the diatom Chaetoceros in the Pacific Ocean. Marine Biology Vol. 151, No. 5, pp. (1899-1906), 0025-3162

Gregory, M.R., (2009). Environmental implications of plastic debris in marine settings entanglement, ingestion, smothering, hangers-on, hitch-hiking and alien invasions. Philosophical Transactions of the Royal Society B: Biological Sciences Vol. 364, No. 1526, pp. (2013-2025), 1471-2970

Grob, C.; Hartmann, M.; Zubkov, M.V.\&Scanlan, D.J., (2011). Invariable biomass-specific primary production of taxonomically discrete picoeukaryote groups across the Atlantic Ocean. Environmental Microbiology Vol., No. pp. 1462-2920

Gruber, N., (2011). Warming up, turning sour, losing breath: ocean biogeochemistry under global change. Phil. Trans. R. Soc. A. Vol. 369, No. 1943, pp. (1980-1996), 1471-2962

Hall-Spencer, J.M.; Rodolfo-Metalpa, R.; Martin, S.; Ransome, E.; Fine, M.; Turner, S.M., et al., (2008). Volcanic carbon dioxide vents show ecosystem effects of ocean acidification. Nature Vol. 454, No. 7200, pp. (96-99), 1476-4687

Harwani, S.; Henry, R.W.; Rhee, A.; Kappes, M.A.; Croll, D.A.; Petreas, M., et al., (2011). Legacy and contemporary persistent organic pollutants in North Pacific albatross. Environmental Toxicology and Chemistry Vol. 30, No. 11, pp. (2562-2569), 1552-8618

Hasler, H.\&Ott, J.A., (2008). Diving down the reefs? Intensive diving tourism threatens the reefs of the northern Red Sea. Marine Pollution Bulletin Vol. 56, No. 10, pp. (17881794), 0025-326X

Hawkes, L.A.; Broderick, A.C.; Godfrey, M.H.\&Godley, B.J., (2007). Investigating the potential impacts of climate change on a marine turtle population. Global Change Biology Vol. 13, No. 5, pp. (923-932), 1365-2486

Hoegh-Guldberg, O.\&Bruno, J.F., (2010). The Impact of Climate Change on the World's Marine Ecosystems. Science Vol. 328, No. 5985, pp. (1523-1528), 1095-9203

Hoepner, T.\&Lattemann, S., (2003). Chemical impacts from seawater desalination plants - a case study of the northern Red Sea. Desalination Vol. 152, No. 1-3, pp. (133-140), 0011-9164 
Holmer, M.; Argyrou, M.; Dalsgaard, T.; Danovaro, R.; Diaz-Almela, E.; Duarte, C.M., et al., (2008). Effects of fish farm waste on Posidonia oceanica meadows: Synthesis and provision of monitoring and management tools. Marine Pollution Bulletin Vol. 56, No. 9, pp. (1618-1629), 0025-326X

Hutchinson, G.E., (1961). The Paradox of the Plankton. The American Naturalist Vol. 95, No. 882, pp. (137-145), 00030147

Ignatiades, L.; Gotsis-Skretas, O.; Pagou, K.\&Krasakopoulou, E., (2009). Diversification of phytoplankton community structure and related parameters along a large-scale longitudinal east $\beta €^{\prime \prime}$ west transect of the Mediterranean Sea. Journal of Plankton Research Vol. 31, No. 4, pp. (411-428), 1464-3774

Invers, O.; Romero, J.\&Pérez, M., (1997). Effects of $\mathrm{pH}$ on seagrass photosynthesis: a laboratory and field assessment. Aquatic Botany Vol. 59, No. 3-4, pp. (185-194), 03043770

Irwin, A.J.\&Oliver, M.J., (2009). Are ocean deserts getting larger? Geophysical Research Letters Vol. 36, No. 18, pp. (L18609), 0094-8276

Israel, A.\&Hophy, M., (2002). Growth, photosynthetic properties and Rubisco activities and amounts of marine macroalgae grown under current and elevated seawater $\mathrm{CO} 2$ concentrations. Global Change Biology Vol. 8, No. 9, pp. (831-840), 1365-2486

Jacobsen, J.K.; Massey, L.\&Gulland, F., (2010). Fatal ingestion of floating net debris by two sperm whales (Physeter macrocephalus). Marine Pollution Bulletin Vol. 60, No. 5, pp. (765-767), 0025-326X

Kähler, P.; Oschlies, A.; Dietze, H.\&Koeve, W., (2010). Oxygen, carbon, and nutrients in the oligotrophic eastern subtropical North Atlantic. Biogeosciences Vol. 7, No. 3, pp. (1143-1156), 1726-4189

Karakassis, I.; Tsapakis, M.; Hatziyanni, E.; Papadopoulou, K.N.\&Plaiti, W., (2000). Impact of cage farming of fish on the seabed in three Mediterranean coastal areas. ICES Journal of Marine Science Vol. 57, No. 5, pp. (1462-1471), 1095-9289

Karamanlidis, A.A.; Androukaki, E.; Adamantopoulou, S.; Chatzispyrou, A.; Johnson, W.M.; Kotomatas, S., et al., (2008). Assessing accidental entanglement as a threat to the Mediterranean monk seal Monachus monachus Endangered Species Research Vol. 5, No. 2-3, pp. (205-213), 1613-4796

Karl, D.M.; BjoKrkman, K.M.; Dore, J.E.; Fujieki, L.; Hebel, D.V.; Houlihan, T., et al., (2001). Ecological nitrogen-to-phosphorus stoichiometry at station ALOHA. Deep Sea Research Part II: Topical Studies in Oceanography Vol. 48, No. 8-9, pp. (1529-1566), 0967-0645

Karl, D.M.; Christian, J.R.; Dore, J.E.; Hebel, D.V.; Letelier, R.M.; Tupas, L.M., et al., (1996). Seasonal and interannual variability in primary production and particle flux at Station ALOHA. Deep Sea Research Part II: Topical Studies in Oceanography Vol. 43, No. 2-3, pp. (539-568), 0967-0645

Katsanevakis, S.; Tsiamis, K.; Ioannou, G.; Michailidis, N.\&Zenetos, A., (2009). Inventory of alien marine species of Cyprus Mediterranean Marine Science Vol. 10, No. 2, pp. (109133), 1791-6763

Keeling, R.F.; Körtzinger, A.\&Gruber, N., (2010). Ocean Deoxygenation in a Warming World. Annual Review of Marine Science Vol. 2, No. 1, pp. (199-229), 1941-0611

Kirkham, A.R.; Jardillier, L.E.; Tiganescu, A.; Pearman, J.; Zubkov, M.V.\&Scanlan, D.J., (2011). Basin-scale distribution patterns of photosynthetic picoeukaryotes along an 
Atlantic Meridional Transect. Environmental Microbiology Vol. 13, No. 4, pp. (975990), 1462-2920

Krom, M.D.; Emeis, K.C.\&Van Cappellen, P., (2010). Why is the Eastern Mediterranean phosphorus limited? Progress In Oceanography Vol. 85, No. 3-4, pp. (236-244), 00796611

Krom, M.D.; Thingstad, T.F.; Brenner, S.; Carbo, P.; Drakopoulos, P.; Fileman, T.W., et al., (2005). Summary and overview of the CYCLOPS P addition Lagrangian experiment in the Eastern Mediterranean. Deep Sea Research Part II: Topical Studies in Oceanography Vol. 52, No. 22-23, pp. (3090-3108), 0967-0645

Kustka, A.; Sañudo-Wilhelmy, S.; Carpenter, E.J.; Capone, D.G.\&Raven, J.A., (2003). A revised estimate of the iron use efficiency of nitrogen fixation, with special reference to the marine cyanobacterium Trichodesmium spp. (Cyanophyta). Journal of Phycology Vol. 39, No. 1, pp. (12-25), 0022-3646

Labiosa, R.G.; Arrigo, K.R.; Genin, A.; Monismith, S.G.\&Van Dijken, G., (2003). The interplay between upwelling and deep convective mixing in determining the seasonal phytoplankton dynamics in the Gulf of Aqaba: Evidence from SeaWiFS and MODIS. Limnology and Oceanography Vol. 48, No. 6, pp. (2355-2368 ), 0024-3590

Lasram, F.B.R.\&Mouillot, D., (2009). Increasing southern invasion enhances congruence between endemic and exotic Mediterranean fish fauna. Biological Invasions Vol. 11, No. 3, pp. (697-711), 1573-1464

Law, K.L.; Morét-Ferguson, S.; Maximenko, N.A.; Proskurowski, G.; Peacock, E.E.; Hafner, J., et al., (2010). Plastic Accumulation in the North Atlantic Subtropical Gyre. Science Vol. 329, No. 5996, pp. (1185-1188), 1095-9203

Le Moal, M.; Collin, H.\&Biegala, I.C., (2011). Intriguing diversity among diazotrophic picoplankton along a Mediterranean transect: a dominance of rhizobia. Biogeosciences Vol. 8, No. 3, pp. (827-840), 1726-4189

Lejeusne, C.; Chevaldonné, P.; Pergent-Martini, C.; Boudouresque, C.F.\&Pérez, T., (2010). Climate change effects on a miniature ocean: the highly diverse, highly impacted Mediterranean Sea. Trends in ecology E evolution (Personal edition) Vol. 25, No. 4, pp. (250-260), 0169-5347

Li, B.; Karl, D.M.; Letelier, R.M.\&Church, M.J., (2011). Size-dependent photosynthetic variability in the North Pacific Subtropical Gyre. Marine Ecology Progress Series Vol. 440, No. pp. (27-40), 1616-1599

Lindell, D.\&Post, A.F., (1995). Ultraphytoplankton succession is triggered by deep winter mixing in the Gulf of Aqaba (Eilat), Red Sea. Limnology and Oceanography Vol. 40, No. 6, (0024-3590), pp. (1130-1141), 0024-3590

Liu, H.; Probert, I.; Uitz, J.; Claustre, H.; Aris-Brosou, S.; Frada, M., et al., (2009). Extreme diversity in noncalcifying haptophytes explains a major pigment paradox in open oceans. Proceedings - National Academy Of Sciences USA Vol. 106, No. 31, pp. (1280312808), 0027-8424

Liu, J.; Weinbauer, M.G.; Maier, C.; Dai, M.\&Gattuso, J.-P., (2010). Effect of ocean acidification on microbial diversity and on microbe-driven biogeochemistry and ecosystem functioning Aquatic Microbial Ecology Vol. 61, No. 3, pp. (291-305), 16161564

Lloret, J., (2010). Human health benefits supplied by Mediterranean marine biodiversity. Marine Pollution Bulletin Vol. 60, No. 10, pp. (1640-1646), 0025-326X 
Lomas, M.W.; Burke, A.L.; Lomas, D.A.; Bell, D.W.; Shen, C.; Dyhrman, S.T., et al., (2010). Sargasso Sea phosphorus biogeochemistry: an important role for dissolved organic phosphorus (DOP). Biogeosciences Vol. 7, No. 2, pp. (695-710), 1726-4189

Lomas, M.W.\&Moran, S.B., (2011). Evidence for aggregation and export of cyanobacteria and nano-eukaryotes from the Sargasso Sea Euphotic zone. Biogeosciences Vol. 8, No. 1, pp. (203-216), 1726-4189

MacKenzie, B.R.; Mosegaard, H.\&Rosenberg, A.A., (2009). Impending collapse of bluefin tuna in the northeast Atlantic and Mediterranean. Conservation Letters Vol. 2, No. 1, pp. (26-35), 1755-263X

Mackey, K.R.M.; Labiosa, R.G.; Calhoun, M.; Street, J.H.; Post, A.F.\&Paytan, A., (2007). Phosphorus availability, phytoplankton community dynamics, and taxon-specific phosphorus status in the Gulf of Aqaba, Red Sea. Limnology and Oceanography Vol. 52, No. 2, pp. (873-885), 0024-3590

Malmstrom, R.R.; Coe, A.; Kettler, G.C.; Martiny, A.C.; Frias-Lopez, J.; Zinser, E.R., et al., (2010). Temporal dynamics of Prochlorococcus ecotypes in the Atlantic and Pacific oceans. ISME Journal Vol. 4, No. 10, pp. (1252-1264), 1751-7362

Mandalakis, M.\&Stephanou, E.G., (2002). Study of atmospheric PCB concentrations over the eastern Mediterranean Sea. Journal of Geophysical Research Vol. 107, No. D23, pp. (4716), 2156-2202

Marañón, E.; Fernández, A.; Mouriño-Carballido, B.; Martínez-García, S.; Teira, E.; Cermeño, P., et al., (2010). Degree of oligotrophy controls the response of microbial plankton to Saharan dust Limnology and Oceanography Vol. 55, No. 6, pp. (2339-2352), 00243590

Marinov, I.; Doney, S.C.\&Lima, I.D., (2010). Response of ocean phytoplankton community structure to climate change over the 21st century: partitioning the effects of nutrients, temperature and light. Biogeosciences Discuss Vol. 7, No. 3, pp. (45654606), 1810-6285

Markaki, Z.; Loÿe-Pilot, M.D.; Violaki, K.; Benyahya, L.\&Mihalopoulos, N., (2010). Variability of atmospheric deposition of dissolved nitrogen and phosphorus in the Mediterranean and possible link to the anomalous seawater N/P ratio. Marine Chemistry Vol. 120, No. 1-4, pp. (187-194), 0304-4203

Martin, S.\&Gattuso, J.-P., (2009). Response of Mediterranean coralline algae to ocean acidification and elevated temperature. Global Change Biology Vol. 15, No. 8, pp. (2089-2100), 1365-2486

Martin, S.; Rodolfo-Metalpa, R.; Ransome, E.; S, R.; Buia, M.C.; Gattuso, J.P., et al., (2008). Effects of naturally acidified seawater on seagrass calcareous epibionts. Biology Letters Vol. 4, No. 6, pp. (689-692), 1744-957X

Martinez-Garcia, S.; Fernandez, E.; Calvo-Diaz, A.; Maranon, E.; Moran, X.A.G.\&Teira, E., (2010). Response of heterotrophic and autotrophic microbial plankton to inorganic and organic inputs along a latitudinal transect in the Atlantic Ocean. Biogeosciences Vol. 7, No. 5, pp. (1701-1713), 1726-4189

Martiny, A.C.; Huang, Y.\&Li, W., (2009). Occurrence of phosphate acquisition genes in Prochlorococcus cells from different ocean regions. Environmental Microbiology Vol. 11, No. 6, pp. (1340-1347), 1462-2920

Mary, I.; Heywood, J.L.; Fuchs, B.M.; Amann, R.; Tarran, G.A.; Burkill, P.H., et al., (2006). SAR11 dominance among metabolically active low nucleic acid bacterioplankton in 
surface waters along an Atlantic meridional transect. Aquatic Microbial Ecology Vol. 45, No. 2, pp. (107-113), 0948-3055

Masquelier, S.\&Vaulot, D., (2008). Distribution of micro-organisms along a transect in the South-East Pacific Ocean (BIOSOPE cruise) using epifluorescence microscopy. Biogeosciences Vol. 5, No. 2, pp. (311-321), 1726-4189

Massana, R.\&Pedrós-Alió, C., (2008). Unveiling new microbial eukaryotes in the surface ocean. Current Opinion in Microbiology Vol. 11, No. 3, pp. (213-218), 1369-5274

Mather, R.L.; Reynolds, S.E.; Wolff, G.A.; Williams, R.G.; Torres-Valdes, S.; Woodward, E.M.S., et al., (2008). Phosphorus cycling in the North and South Atlantic Ocean subtropical gyres. Nature Geoscience Vol. 1, No. 7, pp. (439-443), 1752-0894

Maximenko, N.; Hafner, J.\&Niiler, P., (2011). Pathways of marine debris derived from trajectories of Lagrangian drifters. Marine Pollution Bulletin Vol., No. pp. 0025-326X

Mazzariol, S.; Di Guardo, G.; Petrella, A.; Marsili, L.; Fossi, C.M.; Leonzio, C., et al., (2011). Sometimes Sperm Whales (Physeter macrocephalus) Cannot Find Their Way Back to the High Seas: A Multidisciplinary Study on a Mass Stranding. PLoS ONE Vol. 6, No. 5, pp. (e19417), 1932-6203

McClain, C.R.; Signorini, J.R.\&Christian, S.R., (2004). Subtropical gyre variability observed by ocean-color satellites. Deep Sea Research Part II Vol. 51, No. 1-3, pp. (281-301), 09670645

Moisander, P.H.; Beinart, R.A.; Hewson, I.; White, A.E.; Johnson, K.S.; Carlson, C.A., et al., (2010). Unicellular Cyanobacterial Distributions Broaden the Oceanic $\mathrm{N}_{2}$ Fixation Domain. Science Vol. 327, No. 5972, pp. (1512-1514), 1095-9203

Montefalcone, M.; Albertelli, G.; Morri, C.; Parravicini, V.\&Bianchi, C.N., (2009). Legal protection is not enough: Posidonia oceanica meadows in marine protected areas are not healthier than those in unprotected areas of the northwest Mediterranean Sea. Marine Pollution Bulletin Vol. 58, No. 4, pp. (515-519), 0025-326X

Moore, C.J.; Moore, S.L.; Leecaster, M.K.\&Weisberg, S.B., (2001). A Comparison of Plastic and Plankton in the North Pacific Central Gyre. Marine Pollution Bulletin Vol. 42, No. 12, pp. (1297-1300), 0025-326X

Moore, L.R.; Ostrowski, M.; Scanlan, D.J.; Feren, K.\&Sweetsir, T., (2005). Ecotypic variation in phosphorus-acquisition mechanisms within marine picocyanobacteria. Aquatic Microbial Ecology Vol. 39, No. 3, pp. (257-269), 1616-1564

Moore, M.C.; Mills, M.M.; Achterberg, E.P.; Geider, R.J.; LaRoche, J.; Lucas, M.I., et al., (2009). Large-scale distribution of Atlantic nitrogen fixation controlled by iron availability. Nature Geoscience Vol. 2, No. 12, pp. (867-871), 1752-0894

Morel, A.; Claustre, H.\&Gentili, B., (2010). The most oligotrophic subtropical zones of the global ocean: similarities and differences in terms of chlorophyll and yellow substance. Biogeosciences Vol. 7, No. 10, pp. (3139-3151), 1726-4189

Morel, A.; Gentili, B.; Claustre, H.; Babin, M.; Bricaud, A.; Ras, J., et al., (2007). Optical properties of the "clearest" natural waters. Limnology and Oceanography Vol. 52, No. 1, pp. (217-229), 0024-3590

Mrosovsky, N.; Ryan, G.D.\&James, M.C., (2009). Leatherback turtles: The menace of plastic. Marine Pollution Bulletin Vol. 58, No. 2, pp. (287-289), 0025-326X

Myers, N.; Mittermeier, R.A.; Mittermeier, C.G.; da Fonseca, G.A.B.\&Kent, J., (2000). Biodiversity hotspots for conservation priorities. Nature Vol. 403, No. 6772, pp. (853-858), 1476-4687 
Not, F.; Latasa, M.; Scharek, R.; Viprey, M.; Karleskind, P.; Balagué, V., et al., (2008). Protistan assemblages across the Indian Ocean, with a specific emphasis on the picoeukaryotes. Deep Sea Research Part I: Oceanographic Research Papers Vol. 55, No. 11, pp. (1456-1473), 0967-0637

Orr, J.C.; Fabry, V.J.; Aumont, O.; Bopp, L.; Doney, S.C.; Feely, R.A., et al., (2005). Anthropogenic ocean acidification over the twenty-first century and its impact on calcifying organisms. Nature Vol. 437, No. 7059, pp. (681-686), 1476-4687

Palomera, I.; Olivar, M.P.; Salat, J.; SabatГ®s, A.; Coll, M.; GarcГa, A., et al., (2007). Small pelagic fish in the NW Mediterranean Sea: An ecological review. Progress In Oceanography Vol. 74, No. 2-3, pp. (377-396), 0079-6611

Pedlosky, J., (1998). Ocean Circulation Theory (2 ed.), Springer-Verlag Berlin Heidelberg, 3540-60489-8, New York.

Pergent-Martini, C.; Boudouresque, C.-F.; Pasqualini, V.\&Pergent, G., (2006). Impact of fish farming facilities on Posidonia oceanica meadows: a review. Marine Ecology Vol. 27, No. 4, pp. (310-319), 1439-0485

Perruche, C.; RiviГ"'re, P.; Pondaven, P.\&Carton, X., (2010). Phytoplankton competition and coexistence: Intrinsic ecosystem dynamics and impact of vertical mixing. Journal of Marine Systems Vol. 81, No. 1-2, pp. (99-111), 0924-7963

PlasticsEurope, 2011. Plastics - the Facts 2011 - An analysis of European plastics production, demand and recovery for 2010. http:/ / www.plasticseurope.org/.

Polovina, J.J.; Dunne, J.P.; Woodworth, P.A.\&Howell, E.A., (2011). Projected expansion of the subtropical biome and contraction of the temperate and equatorial upwelling biomes in the North Pacific under global warming. ICES Journal of Marine Science: Journal du Conseil Vol. 68, No. 6, pp. (986-995), 1095-9289

Polovina, J.J.; Howell, E.A.\&Abecassis, M., (2008). Ocean's least productive waters are expanding. Geophys. Res. Lett. Vol. 35, No. 3, pp. (L03618), 0094-8276

Porzio, L.; Buia, M.C.\&Hall-Spencer, J.M., (2011). Effects of ocean acidification on macroalgal communities. Journal of Experimental Marine Biology and Ecology Vol. 400, No. 1-2, pp. (278-287), 0022-0981

Poulton, A.J.; Holligan, P.M.; Hickman, A.; Kim, Y.-N.; Adey, T.R.; Stinchcombe, M.C., et al., (2006). Phytoplankton carbon fixation, chlorophyll-biomass and diagnostic pigments in the Atlantic Ocean. Deep Sea Research Part II: Topical Studies in Oceanography Vol. 53, No. 14-16, pp. (1593-1610), 0967-0645

Pusceddu, A.; Fiordelmondo, C.; Polymenakou, P.; Polychronaki, T.; Tselepides, A.\&Danovaro, R., (2005). Effects of bottom trawling on the quantity and biochemical composition of organic matter in coastal marine sediments (Thermaikos Gulf, northwestern Aegean Sea). Continental Shelf Research Vol. 25, No. 19-20, pp. (2491-2505), 0278-4343

Raimbault, P.\&Garcia, N., (2007). Carbon and nitrogen uptake in the South Pacific Ocean: evidence for efficient dinitrogen fixation and regenerated production leading to large accumulation of dissolved organic matter in nitrogen-depleted waters. Biogeosciences Discuss Vol. 4, No. 5, pp. (3531-3579), 1810-6285

Raimbault, P.; Garcia, N.\&Cerutti, F., (2008). Distribution of inorganic and organic nutrients in the South Pacific Ocean - evidence for long-term accumulation of organic matter in nitrogen-depleted waters. Biogeosciences Vol. 5, No. 2, pp. (281-298), 1810-6285 
Raleigh, V.S., (1999). Trends in world population: how will the millenium compare with the past? Human Reproduction Update Vol. 5, No. 5, pp. (500-505), 1355-4786

Ras, J.; Claustre, H.\&Uitz, J., (2008). Spatial variability of phytoplankton pigment distributions in the Subtropical South Pacific Ocean: comparison between in situ and predicted data. Biogeosciences Vol. 5, No. 2, pp. (353-369), 1726-4189

Raven, J.A., (1998). The twelfth Tansley lecture. Small is beautiful: the picophytoplankton. Functional ecology. Vol. 12, No. 4, pp. (505-513), 1365-2435

Reeves, R.\&Notarbartolo, d.S.G., (2006). The status and distribution of cetaceans in the Black Sea and Mediterranean Sea, The World Conservation Union (IUCN), 137 pp., Malaga, Spain.

Ridame, C.; Le Moal, M.; Guieu, C.; Ternon, E.; Biegala, I.C.; L'Helguen, S., et al., (2011). Nutrient control of $\mathrm{N}_{2}$ fixation in the oligotrophic Mediterranean Sea and the impact of Saharan dust events. Biogeosciences Vol. 8, No. 9, pp. (2773-2783), 17264189

Riebesell, U.; Körtzinger, A.\&Oschlies, A., (2009). Sensitivities of marine carbon fluxes to ocean change. Proceedings of the National Academy of Sciences Vol. 106, No. 49, pp. (20602-20609), 1091-6490

Riemann, L.; Nielsen, T.G.; Kragh, T.; Richardson, K.; Parner, H.; Jakobsen, H.H., et al., (2011). Distribution and production of plankton communities in the subtropical convergence zone of the Sargasso Sea. I. Phytoplankton and bacterioplankton. Marine Ecology Progress Series Vol. 426, No. pp. (57-70), 1616-1599

Rios, L.M.; Jones, P.R.; Moore, C.\&Narayan, U.V., (2010). Quantitation of persistent organic pollutants adsorbed on plastic debris from the Northern Pacific Gyre's "eastern garbage patch". Journal of Environmental Monitoring Vol. 12, No. 12, pp. (2226-2236), 1464-0333

Riser, S.C.\&Johnson, K.S., (2008). Net production of oxygen in the subtropical ocean. Nature Vol. 451, No. 7176, pp. (323-325), 1476-4687

Roberts, C.M.; McClean, C.J.; Veron, J.E.N.; Hawkins, J.P.; Allen, G.R.; McAllister, D.E., et al., (2002). Marine Biodiversity Hotspots and Conservation Priorities for Tropical Reefs. Science Vol. 295, No. 5558, pp. (1280-1284), 0036-8075

Robinson, C.; Holligan, P.; Jickells, T.\&Lavender, S., (2009). The Atlantic Meridional Transect Programme (1995-2012). Deep Sea Research Part II: Topical Studies in Oceanography Vol. 56, No. 15, pp. (895-898), 0967-0645

Rodolfo-Metalpa, R.; Houlbreque, F.; Tambutte, E.; Boisson, F.; Baggini, C.; Patti, F.P., et al., (2011). Coral and mollusc resistance to ocean acidification adversely affected by warming. Nature Climate Change Vol. 1, No. 6, pp. (308-312), 1758-6798

Roy, S.\&Chattopadhyay, J., (2007). Towards a resolution of 'the paradox of the plankton': A brief overview of the proposed mechanisms. Ecological Complexity Vol. 4, No. 1-2, pp. (26-33), 1476-945X

Sabine, C.L.; Feely, R.A.; Gruber, N.; Key, R.M.; Lee, K.; Bullister, J.L., et al., (2004). The Oceanic Sink for Anthropogenic $\mathrm{CO}_{2}$. Science Vol. 305, No. 5682, pp. (367-371), 00368075

Sara, G.; Bianchi, C.N.\&Morri, C., (2005). Mating behaviour of the newly-established ornate wrasse Thalassoma pavo (Osteichthyes: Labridae) in the Ligurian Sea (northwestern Mediterranean). Journal of the Marine Biological Association of the United Kingdom Vol. 85, No. 01, pp. (191-196), 1469-7769 
Sarmento, H.; Montoya, J.M.; Vázquez-Domínguez, E.; Vaqué, D.\&Gasol, J.M., (2010). Warming effects on marine microbial food web processes: how far can we go when it comes to predictions? Philosophical Transactions of the Royal Society B: Biological Sciences Vol. 365, No. 1549, pp. (2137-2149), 1471-2970

Schattenhofer, M.; Fuchs, B.M.; Amann, R.; Zubkov, M.V.; Tarran, G.A.\&Pernthaler, J., (2009). Latitudinal distribution of prokaryotic picoplankton populations in the Atlantic Ocean. Environmental Microbiology Vol. 11, No. 8, pp. (2078-2093), 14622920

Schlüter, L.; Henriksen, P.; Nielsen, T.G.\&Jakobsen, H.H., (2011). Phytoplankton composition and biomass across the southern Indian Ocean. Deep Sea Research Part I: Oceanographic Research Papers Vol. 58, No. 5, pp. (546-556), 0967-0637

Seki, M.P.\&Polovina, J.J., (2001). Ocean gyre ecosystems, in: The Encyclopedia of Ocean Sciences, Steele, J. H. et al (eds.), pp. (1959-1964), Academic Press, Ca.3399p, San Diego

Shi, X.L.; Lepère, C.; Scanlan, D.J.\&Vaulot, D., (2011). Plastid 16S rRNA Gene Diversity among Eukaryotic Picophytoplankton Sorted by Flow Cytometry from the South Pacific Ocean. PLoS ONE Vol. 6, No. 4, pp. (e18979), 1932-6203

Shushkina, E.A.; Vinogradov, M.E.; Lebedeva, L.P.\&Anokhina, L.L., (1997). Productivity Characteristics of Epipelagic Communities of the World's Oceans. Oceanology Vol. 37, No. 3, pp. (346-353), 0001-4370

Signorini, S.R.\&McClain, C.R., (2011). Subtropical gyre variability as seen from satellites. Remote Sensing Letters Vol. 3, No. 6, pp. (471-479), 2150-704X

Silverman, J.; Lazar, B.; Cao, L.; Caldeira, K.\&Erez, J., (2009). Coral reefs may start dissolving when atmospheric $\mathrm{CO}_{2}$ doubles. Geophysical Research Letters Vol. 36, No. 5, pp. (L05606), 0094-8276

Siokou-Frangou, I.; Christaki, M.; Mazzocchi, G.; Montresor, M.; Ribera D'Alcalá, M.\&Vaqué D, Z.A., (2010). Plankton in the open Mediterranean Sea: a review. Biogeosciences Vol. 7, No. 5, pp. (1543-1586), 1726-4189

Sommer, U.; Stibor, H.; Katechakis, A.; Sommer, F.\&Hansen, T., (2002). Pelagic food web configurations at different levels of nutrient richness and their implications for the ratio fish production:primary production. Hydrobiologia Vol. 484, No. 1, pp. (11-20), 1573-5117

Steinberg, D.K.; Carlson, C.A.; Bates, N.R.; Johnson, R.J.; Michaels, A.F.\&Knap, A.H., (2001). Overview of the US JGOFS Bermuda Atlantic Time-series Study (BATS): a decadescale look at ocean biology and biogeochemistry. Deep Sea Research Part II: Topical Studies in Oceanography Vol. 48, No. 8-9, pp. (1405-1447), 0967-0645

Stramma, L.; Schmidtko, S.; Levin, L.A.\&Johnson, G.C., (2010). Ocean oxygen minima expansions and their biological impacts. Deep Sea Research Part I: Oceanographic Research Papers Vol. 57, No. 4, pp. (587-595), 0967-0637

Taboada, G., Fernando; González Gil, R.; Höfer, J.; González, S.\&Anadón, R., (2010). Trichodesmium spp. population structure in the eastern North Atlantic subtropical gyre. Deep Sea Research Part I: Oceanographic Research Papers Vol. 57, No. 1, pp. (6577), 0967-0637

Tanaka, T.; Thingstad, T.F.; Christaki, U.; Colombet, J.; Cornet-Barthaux, V.; Courties, C., et al., (2011). Lack of P-limitation of phytoplankton and heterotrophic prokaryotes in 
surface waters of three anticyclonic eddies in the stratified Mediterranean Sea. Biogeosciences Vol. 8, No. 2, pp. (525-538), 1726-4189

Tanaka, T.; Zohary, T.; Krom, M.D.; Law, C.S.; Pitta, P.; Psarra, S., et al., (2007). Microbial community structure and function in the Levantine Basin of the eastern Mediterranean. Deep Sea Research Part I: Oceanographic Research Papers Vol. 54, No. 10, pp. (1721-1743), 0967-0637

Thébault, H.; Rodriguez y Baena, A.M.; Andral, B.; Barisic, D.; Albaladejo, J.B.; Bologa, A.S., et al., (2008). 137Cs baseline levels in the Mediterranean and Black Sea: A crossbasin survey of the CIESM Mediterranean Mussel Watch programme. Marine Pollution Bulletin Vol. 57, No. 6-12, pp. (801-806), 0025-326X

Thiel, M.; Bravo, M.; Hinojosa, I.A.; Luna, G.; Miranda, L.; Núñez, P., et al., (2011). Anthropogenic litter in the SE Pacific: an overview of the problem and possible solutions. Journal of Integrated Coastal Zone Management Vol. 11, No. 1, pp. (115-134), 1477-7835

Thingstad, T.F.; Krom, M.D.; Mantoura, R.F.C.; Flaten, G.A.F.; Groom, S.; Herut, B., et al., (2005). Nature of Phosphorus Limitation in the Ultraoligotrophic Eastern Mediterranean. Science Vol. 309, No. 5737, pp. (1068-1071), 1095-9203

Thomalla, S.J.; Waldron, H.N.; Lucas, M.I.; Read, J.F.; Ansorge, I.J.\&Pakhomov, E., (2010). Phytoplankton distribution and nitrogen dynamics in the Southwest Indian subtropical gyre and Southern Ocean Waters. Ocean Science Discussions Vol. 7, No. 4, pp. (1347-1403), 1812-0822

Thompson, R.C.; Olsen, Y.; Mitchell, R.P.; Davis, A.; Rowland, S.J.; John, A.W.G., et al., (2004). Lost at Sea: Where Is All the Plastic? Science Vol. 304, No. 5672, pp. (838), 1095-9203

Thrush, S.F.; Gray, J.S.; Hewitt, J.E.\&Ugland, K.I., (2006). Predicting the effects of habitat homogenization on marine biodiversity. Ecological Applications Vol. 16, No. 5, pp. (1636-1642), 1051-0761

Trenberth, K.E.; Jones, P.D.; Ambenje, P.; Bojariu, R.; Easterling, D.; Klein, T.A., et al., (2007). Series. Observations: Surface and Atmospheric Climate Change. In: Climate Change 2007: The Physical Science Basis. Contribution of Working Group I to the Fourth Assessment Report of the Intergovernmental Panel on Climate Change, (Solomon, S., Qin, D., Manning, M., Chen, Z., Marquis, M., Averyt, K.B., Tignor, M., Miller, H.L., (eds.)), Cambridge University Press, Cambridge and New York.

Treusch, A.H.; Vergin, K.L.; Finlay, L.A.; Donatz, M.G.; Burton, R.M.; Carlson, C.A., et al., (2009). Seasonality and vertical structure of microbial communities in an ocean gyre. ISME Journal Vol. 3, No. 10, pp. (1148-1163), 1751-7370

Tsubouchi, T.; Suga, T.\&Hanawa, K., (2009). Indian Ocean subtropical mode water: its water characteristics and spatial distribution. Ocean Science Discussions Vol. 6, No. 1, pp. (723-739), 1812-0822

Tudela, S., (2004). Ecosystem effects of fishing in the Mediterranean: an analysis of the major threats of fishing gear and practices to biodiversity and marine habitats Studies and reviews. General Fisheries Commission for the Mediterranean Vol., No. 74, pp. (1-44), $1020-7236$

Turley, C.M., (1999). The changing Mediterranean Sea - a sensitive ecosystem? Progress In Oceanography Vol. 44, No. 1-3, pp. (387-400), 0079-6611 
Tyrrell, T., (1999). The relative influences of nitrogen and phosphorus on oceanic primary production. Nature Vol. 400, No. 6744, pp. (525-531), 0028-0836

Tyrrell, T., (2011). Anthropogenic modification of the oceans. Phil. Trans. R. Soc. A. Vol. 369, No. 1938, pp. (887-908), 1471-2962

UnitedStatesCensusBureau, 2011. World Population, http://www.census.gov/main/www/popclock.html.

Van Mooy, B.A.S.\&Devol, A.H., (2008). Assessing nutrient limitation of Prochlorococcus in the North Pacific subtropical gyre by using an RNA capture method. Limnology and Oceanography Vol. 53, No. 1, pp. (78-88), 0024-3590

Van Mooy, B.A.S.; Rocap, G.; Fredricks, H.F.; Evans, C.T.\&Devol, A.H., (2006). Sulfolipids dramatically decrease phosphorus demand by picocyanobacteria in oligotrophic marine environments. Proceedings - National Academy Of Sciences USA Vol. 103, No. 23, pp. (8607-8612), 0027-8424

Viviani, D.A.; Björkman, K.M.; Karl, D.M.\&Church, M.J., (2011). Plankton metabolism in surface waters of the tropical and subtropical Pacific Ocean. Aquatic Microbial Ecology Vol. 62, No. 1, pp. (1-12), 1616-1564

Wagener, T.; Guieu, C.; Losno, R.; Bonnet, S.\&Mahowald, N., (2008). Revisiting atmospheric dust export to the Southern Hemisphere ocean: Biogeochemical implications. Global Biogeochem. Cycles Vol. 22, No. 2, pp. (GB2006), 0886-6236

Wilson, C.\&Qiu, X., (2008). Global distribution of summer chlorophyll blooms in the oligotrophic gyres. Progress In Oceanography Vol. 78, No. 2, pp. (107-134), 0079-6611

Wu, J.; Sunda, W.; Boyle, E.A.\&Karl, D.M., (2000). Phosphate Depletion in the Western North Atlantic Ocean. Science Vol. 289, No. 5480, pp. (759-762), 0036-8075

Young, L.C.; Vanderlip, C.; Duffy, D.C.; Afanasyev, V.\&Shaffer, S.A., (2009). Bringing Home the Trash: Do Colony-Based Differences in Foraging Distribution Lead to Increased Plastic Ingestion in Laysan Albatrosses? PLoS ONE Vol. 4, No. 10, pp. (e7623), 19326203

Zehr, J.P.\&Kudela, R.M., (2011). Nitrogen cycle of the open ocean: from genes to ecosystems. Annual Review of Marine Science Vol. 3, No. pp. (197-225), 1941-1405

Zenetos, A.; Gofas, S.; Verlaque, M.; Cinar, M.E.; García, R.E.; Azzurro, E., et al., (2010). Alien species in the Mediterranean by 2010. A contribution to the application of European Union's Marine Strategy Framework Directive (MSFD). Part I. Spatial distribution. Mediterranean Marine Science Vol. 11, No. 2, pp. (481-493), 1791-6763

Zenetos, A.; Siokou-Frangou, I.\&Gotsis Skretas, O., (2002). The Mediterranean Sea - blue oxygen-rich, nutrient-poor waters, Technical Report. European Environment Agency, Copenhagen, Denmark. 


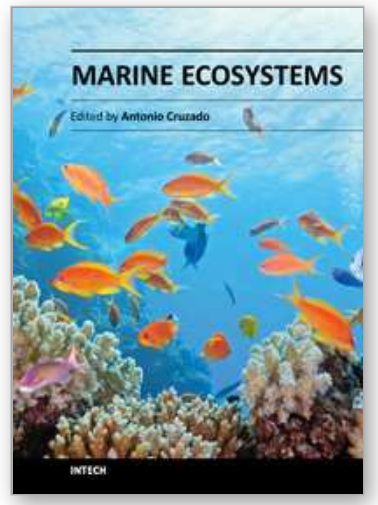

\author{
Marine Ecosystems \\ Edited by Dr. Antonio Cruzado
}

ISBN 978-953-51-0176-5

Hard cover, 310 pages

Publisher InTech

Published online 02, March, 2012

Published in print edition March, 2012

Marine ecosystems, a very wide topic, includes many different processes, groups of organisms and geographical peculiarities. The objective of this book is to present various topics of great importance for understanding the marine ecosystems, what they are, how they work and how we can model them in order to forecast their behaviour under changing conditions. They have been thoroughly reviewed and accepted for publication. The chapters cover aspects such as: Threats to ultraoligotrophic marine ecosystems (Ch. 1); Modelling the pelagic ecosystem dynamics: the NW Mediterranean (Ch. 2); The marine ecosystem of the Subantarctic, Prince Edward Islands (Ch. 3); Meiofauna as a tool for marine ecosystem biomonitoring (Ch. 4); Chemical interactions in Antarctic marine benthic ecosystems (Ch. 5); An Interdisciplinary Approach on Erosion Mitigation for Coral Reef Protection- A Case Study from the Eastern Caribbean (Ch. 6); A revisit to the evolution and ecophysiology of the Labyrinthulomycetes (Ch. 7); Seabed mapping and marine spatial planning: a case-study from a Swedish marine protected area (Ch. 8); Management strategies to limit the impact of bottom trawling on VMEs in the High Seas of the SW Atlantic (Ch. 9); Hydrocarbon contamination and the swimming behavior of the estuarine copepod Eurytemora affinis (Ch. 10), and Interactions between marine ecosystems and tourism on the Adriatic and Mediterranean (Ch. 11).

\title{
How to reference
}

In order to correctly reference this scholarly work, feel free to copy and paste the following:

Demetris Kletou and Jason M. Hall-Spencer (2012). Threats to Ultraoligotrophic Marine Ecosystems, Marine Ecosystems, Dr. Antonio Cruzado (Ed.), ISBN: 978-953-51-0176-5, InTech, Available from: http://www.intechopen.com/books/marine-ecosystems/threats-to-ultraoligotrophic-marine-ecosystems

\section{INTECH}

open science | open minds

\section{InTech Europe}

University Campus STeP Ri

Slavka Krautzeka 83/A

51000 Rijeka, Croatia

Phone: +385 (51) 770447

Fax: +385 (51) 686166

www.intechopen.com
InTech China

Unit 405, Office Block, Hotel Equatorial Shanghai

No.65, Yan An Road (West), Shanghai, 200040, China

中国上海市延安西路 65 号上海国际贵都大饭店办公楼 405 单元

Phone: +86-21-62489820

Fax: $+86-21-62489821$ 
(C) 2012 The Author(s). Licensee IntechOpen. This is an open access article distributed under the terms of the Creative Commons Attribution 3.0 License, which permits unrestricted use, distribution, and reproduction in any medium, provided the original work is properly cited. 